\title{
Oxaspirol B with p97 Inhibitory Activity and Other Oxaspirols from Lecythophora sp. FL1375 and FL1031, Endolichenic Fungi Inhabiting Parmotrema tinctorum and Cladonia evansii
}

\author{
E. M. Kithsiri Wijeratne ${ }^{\dagger}$, G. M. Kamal B. Gunaherath ${ }^{\dagger, \ddagger}$, Vanessa M. Chapla $^{\dagger}$, , Joseph \\ Tillotson ${ }^{\perp}$, Fabian de la Cruz ${ }^{\perp}$, MinJing Kang ${ }^{\perp}$, Jana M. U'Ren", Angela R. Araujo§, A. \\ Elizabeth Arnold" ${ }^{\|, \#}$, Eli Chapman ${ }^{\perp}$, and A. A. Leslie Gunatilaka ${ }^{*}$, \\ †Natural Products Center, School of Natural Resources and the Environment, College of \\ Agriculture and Life Sciences, University of Arizona, 250 East Valencia Road, Tucson, Arizona \\ 85706, United States \\ ‡Department of Chemistry, Open University of Sri Lanka, Nugegoda 10250, Sri Lanka \\ §Departamento de Química Orgânica, Instituto de Química, UNESP, Universidade Estadual \\ Paulista, Araraquara, Sao Paulo 14800-900, Brazil \\ ${ }^{\perp}$ Department of Pharmacology and Toxicology, College of Pharmacy, University of Arizona, \\ Tucson, Arizona 85721, United States \\ "School of Plant Sciences, College of Agriculture and Life Sciences, University of Arizona, \\ Tucson, Arizona 85721, United States \\ \#Department of Ecology and Evolutionary Biology, University of Arizona, Tucson, Arizona 85721, \\ United States
}

\begin{abstract}
A new metabolite, oxaspirol D (4), together with oxaspirols B (2) and C (3) were isolated from Lecythophora sp. FL1375, an endolichenic fungus isolated from Parmotrema tinctorum, whereas Lecythophora sp. FL1031 inhabiting the lichen Cladonia evansii afforded oxaspirols A (1), B (2), and C (3). Of these, oxaspirol B (2) showed moderate p97 ATPase inhibitory activity. A detailed characterization of all oxaspirols was undertaken because structures proposed for known oxaspirols have involved incomplete assignments of NMR spectroscopic data leading only to their planar structures. Thus, the naturally occurring isomeric mixture (2a and $\mathbf{2 b}$ ) of oxaspirol B was separated as their diacetates (5a and $\mathbf{5 b}$ ) and the structures and absolute configurations of $\mathbf{1}, \mathbf{2 a}$, $\mathbf{2 b}, \mathbf{3}$, and $\mathbf{4}$ were determined by the application of spectroscopic techniques including two-
\end{abstract}

\footnotetext{
*Corresponding Author Tel: (520) 621-9932. Fax: (520) 621-8378. leslieg1@email.arizona.edu. ASSOCIATED CONTENT

Supporting Information

The Supporting Information is available free of charge on the ACS Publications website at DOI: 10.1021/acs.jnat-prod.5b00986. 1D and 2D NMR spectra of oxaspirols A-D (1-4) and their derivatives 1a, 5a, 5b, 7a, and $7 \mathbf{b} ;{ }^{1} \mathrm{H}$ and ${ }^{13} \mathrm{C}$ NMR data for $6 \mathbf{a}$ and 6b; ${ }^{1} \mathrm{H}$ NMR spectra of $8 \mathbf{a}, 9 \mathbf{9}, \mathbf{1 0 a}$, and $\mathbf{1 0 b}$, and NOEDIFF spectra of $8 \mathbf{a}$ and $9 \mathbf{a}$; figures depicting possible intramolecular $\mathrm{H}-$ bonding in $\mathbf{8 a}$ and $9 \mathbf{a}$ preventing retro-aldol process and proposed mechanism for stereospecific reduction of $\mathbf{2 a}$ and $\mathbf{2} \mathbf{b}$ with $\mathrm{NaBH}_{4} /$ $\mathrm{CeCl}_{3}$ to afford 10a and 10b (PDF)

The authors declare no competing financial interest.
} 
dimensional NMR and the modified Mosher's ester method. Oxaspirol B (2) and its diacetates 5a and $\mathbf{5 b}$ were evaluated for their ATPase inhibitory activities of p97, p97 mutants, and other ATPutilizing enzymes, and only $\mathbf{2}$ was found to be active, indicating the requirement of some structural features in oxaspirols for their activity. Additional biochemical and cellular assays suggested that $\mathbf{2}$ was a reversible, non-ATP competitive, and specific inhibitor of p97.

\section{Graphical Abstract}

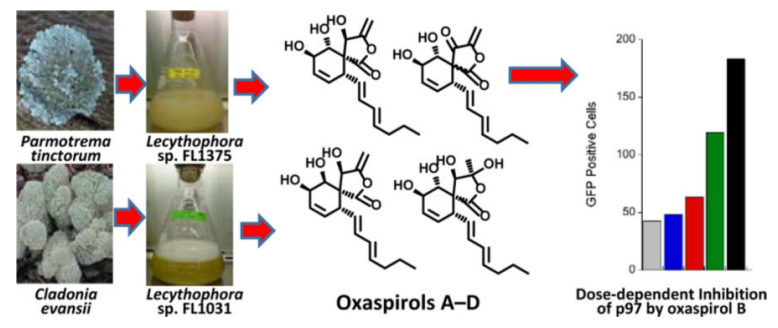

A type II AAA+ (ATPase associated with various cellular activities), p97 uses the binding and hydrolysis of ATP to generate a force to affect the transformation of a polypeptide substrate. This remarkable molecular machine recognizes ubiquitylated polypeptides in a variety of contexts to carry out diverse and numerous cellular functions. Generally, p97 exerts a force to segregate proteins from other proteins, protein complexes, or biological membranes; thus, it has been named a segregase. This activity is needed in physiologic processes that include endoplasmic reticulum associated degradation (ERAD), transcription factor regulation, homotypic membrane fusion, and cell-cycle regulation. The observation that upregulation of p97 correlated with a poor clinical outcome in numerous cancers coupled with its role in transcription factor modulation, protein quality control, and cellcycle control have led to the suggestion that $\mathrm{p} 97$ might be a good target for cancer chemotherapeutics.' Recent validation of p97 as an anticancer target has led to the development of a series of synthetic quinazoline-2,4-diamine-based small-molecule inhibitors of which DBeQ and ML240 (Figure S1, Supporting Information) have been found to be promising early leads. In our continuing search for small-molecule anticancer agents, a multidisciplinary effort to identify natural product-based modulators of p97 was recently undertaken. Initial work toward this utilized a functional chromatographic technique that led to the identification of three natural product inhibitors of p97, 1-hydroxydehydroherbarin, phomapyrrolidone A, and rheoemodin (Figure S1), each with a different mechanism of action. Subsequent extension of this technique identified oxaspirol B (2) (Figure 1) as the p97 ATPase inhibitory constituent of an extract of the fungus Lecythophora sp.

A more recently developed strategy for the purpose of identifying inhibitors of p97 involved (i) the use of a simple malachite green-based ATPase assay in 384-well format to screen a library of natural product extracts; (ii) bioactivity-guided fractionation of the active extracts for purification and subsequent identification of compounds responsible for $\mathrm{p} 97$ inhibitory activity; (iii) testing of the active compounds for their specificity in single cysteine mutants of p97 namely, p97-Cys0, p97-C209A, and p97-C502A; and (iv) evaluation of active compounds in cell-based assays using HEK293 (human embryonic kidney) cells stably transfected with the ubiquitin fusion degradation (UFD) pathway reporter, $\mathrm{Ub}^{\mathrm{G} 76} \mathrm{~V}_{\mathrm{GFP}}$, and 
the ERAD pathway reporter, TCR $a$-GFP. Application of this strategy led to the identification of several natural product extracts with ATPase activity, including that derived from the endolichenic fungal strain Lecythophora sp. FL1375 (Coniochaetaceae, Coniochaetales, Sordariomycetes, Pezizomycotina, Ascomycota) inhabiting the live thallus of the lichen Parmotrema tinctorum (Lecanorales). This extract was selected to investigate the applicability of a bioactivity-guided fractionation approach to isolate and fully characterize the p97 ATPase inhibitory constituent, oxaspirol B (2). It was also found to contain oxaspirol C (3). When recultured on a large-scale, Lecythophora sp. FL1375 afforded 2 and a new metabolite, oxaspirol D (4) (Figure 1). Investigation of Lecythophora sp. FL1031 isolated from another lichen, Cladonia evansii (Lecanorales), afforded oxaspirols A (1), B (2), and C (3). Reported herein are the isolation of 1-4; separation of oxaspirol B (2) isomers $\mathbf{2 a}$ and $\mathbf{2 b}$ as their diacetates $\mathbf{5 a}$ and $\mathbf{5 b}$ (Scheme 2); structure elucidation including the determination of the absolute configurations of $\mathbf{1}, \mathbf{2 a}, \mathbf{2 b}, \mathbf{3}$ and $\mathbf{4}$; and characterization of the p97 ATPase inhibitory activity of $\mathbf{2}$. This constitutes the first report of the occurrence of oxaspirols in the fungal genus Lecythophora or in an endosymbiotic fungus. Previous studies have led to the isolation of 5,7-dihydroxy-4,6-dimethylphthalide, 2,5-furandimenthol, tyrosol, lecythoside, and lecythophorin from L. hoffmanni, and (2R)-3(2-hydroxypropyl)-benzene-1,2-diol, kojic acid, 7- $O$-acetylkojic acid, 4-hydroxybenzoic acid, emodin, 7-chloroemodin, and ergosterol-5,8-peroxide from an endophytic Lecythophora sp.

Oxaspirols belong to a rare class of fungal metabolites featuring a 6-alkyl substituted 3methylidene-2-oxaspiro[4,5]-decane core bearing 4-6 chiral centers with undefined stereoconfigurations.' Of the oxaspirols known to date, oxaspirol A (1) was the first to be encountered, and this was isolated as a weakly active antibacterial constituent from a mutant strain of the human pathogenic fungus, Rhodotorula glutinis T-110. Its planar structure has been elucidated with the help of ${ }^{1} \mathrm{H}$ and ${ }^{13} \mathrm{C}$ NMR spectroscopic data and by comparison of these data with those reported for rosigenin. However, no detailed ${ }^{1} \mathrm{H}$ and ${ }^{13} \mathrm{C}$ NMR assignments of $\mathbf{1}$ have been reported. Isolation of oxaspirol B (2) as an inseparable mixture and oxaspirol C (3) have exclusively appeared in Japanese patent literature with incomplete and unassigned NMR spectroscopic data and meagre information on details of their structure elucidation. Additional fungal metabolites containing a core structure similar to oxaspirols include arthropsolides from Arthropsis truncata, massarigenins from Massarina tunicata, spiroleptosphols from Leptosphaeria doliolum, and trichocladinols from Trichocladium opacum.

\section{RESULTS AND DISCUSSION}

Bioactivity-guided fractionation of the EtOAc extract of a potato dextrose broth (PDB) culture of the endolichenic fungus Lecythophora sp. FL1375 with p97 ATPase inhibitory activity yielded a bioactive fraction which on further fractionation afforded metabolites 2-4 of which 2 was found to be the bioactive constituent (Figure 2A). Similar fractionation of the EtOAc extract of a PDB culture of Lecythophora sp. FL1031 yielded metabolites 1-3. The NMR and mass spectroscopic data of 1-4 indicated that they had the same overall oxaspirol skeletal structure including the $E$-configuration $(J=15.0 \mathrm{~Hz})$ for the conjugated 
double bonds of the hepta-1,3-dienyl side chain at C-6 (Figure 1). Comparison of the ${ }^{1} \mathrm{H}$ and ${ }^{13} \mathrm{C}$ NMR data of $\mathbf{1}$ (Table 1) with those reported confirmed its identity as oxaspirol A, for which only the planar structure has been proposed. Oxaspirol A contained five chiral centers (C-4, C-5, C-6, C-9, and C-10) including the spiro center (C-5), and determination of configuration of each of these centers was carried out as described below. The coupling constant $(J=6.4 \mathrm{~Hz}$ ) for $\mathrm{H}-9$ and $\mathrm{H}-10$ of $\mathbf{1}$ (Table 1) suggested diequatorial orientation of these two protons, indicating that the $\mathrm{OH}$ group at $\mathrm{C}-10$ is axial. Because the NOEDIFF experiment of $\mathbf{1}$ did not provide any conclusive information about the configuration of the chiral centers, it was acetylated $\left(\mathrm{Ac}_{2} \mathrm{O} /\right.$ pyridine) to give 4,9,10-triacetyloxaspirol A (1a) (Figure 1). The coupling constant $(J=8.0 \mathrm{~Hz})$ for H-9 and H-10 of 1a (Table 2) was found to be different from that of $\mathbf{1}(J=6.4 \mathrm{~Hz})$, indicating a change of dihedral angle between these two protons as a result of acetylation causing the cyclohexene ring to convert from pseudochair to pseudoboat conformation. In a NOEDIFF experiment, irradiation of H-10 $\left(\delta_{\mathrm{H}} 5.38\right)$ of 1a caused enhancements of the signals at $\delta_{\mathrm{H}} 5.89(\mathrm{H}-4)$ and $3.40(\mathrm{H}-6)$, suggesting that all these protons were cofacial (Figure 3). Determination of the absolute configuration of 1 was achieved by the application of the modified Mosher's ester method. When 1 was treated with $(R)$ - and $(S)$ - $\alpha$-methoxy- $\alpha$-trifluoromethylphenylacetyl chloride $[(R)$ - and $(S)$-MTPA-Cl], esterification exclusively took place at OH-9 yielding $(S)$ - and $(R)$ MTPA esters $1 \mathbf{b}$ and $\mathbf{1 c}$, respectively. Analysis of the $\Delta \delta\left(\delta_{\mathrm{S}}-\delta_{\mathrm{R}}\right)$ values of these two esters suggested that the absolute configuration of C-9 to be $R$ (Figure 4). Thus, based on the foregoing evidence including coupling constants, NOEDIFF, and Mosher's ester data, the structure of oxaspirol A was established as $(4 R, 5 R, 6 R, 9 R, 10 R)$-6-(hepta-1,3-dien)yl-4,9,10trihydroxy-3-methyl-2-oxaspiro[4,5]dec-7-en-1-one (1, Figure 1).

The ${ }^{1} \mathrm{H}$ NMR spectrum of the bioactive metabolite 2 indicated that it consisted of two inseparable isomers $\mathbf{2 a}$ and $\mathbf{2} \mathbf{b}$ in the ratio of ca. 1.0:0.8. Application of ${ }^{1} \mathrm{H}-{ }^{1} \mathrm{H}$ correlation spectroscopy (COSY) and heteronuclear multiple-bond correlation (HMBC) data made it possible to recognize the NMR signals due to each isomer (Figure 5; Figures S10 and S12) and these data suggested that both isomers had the same planar structure proposed previously for oxaspirol B. It was of interest to determine if only one or both isomers (2a and 2b) of oxaspirol B (2) was responsible for its bioactivity. Thus, a variety of methods were attempted to separate the two isomers, and of these only that employing reversed-phase chiral high-performance liquid chromatography (HPLC) was found to be successful (Figure S2). However, on attempted isolation these two isomers were found to interconvert, possibly due to epimerization at the spiro center (C-5) as a result of retro-aldol and aldol processes, suggesting that $\mathbf{2 a}$ and $\mathbf{2 b}$ were configurational isomers at C-5 (Scheme 1). Thus, these two isomers were designated as $(5 R)$-oxaspirol B (2a) and (5S)-oxaspirol B (2b). Epimerization of $\mathbf{2 a}$ and $\mathbf{2 b}$ by retro-aldol and aldol processes was further supported by the fact that acetylation ( $\mathrm{Ac}_{2} \mathrm{O}$ /pyridine) of $\mathbf{2}$ yielded two noninterconvertible 9,10-diacetyloxaspirol B isomers (5a and $\mathbf{5 b}$ ) which were separable by chiral HPLC (Scheme 2). The coupling constant $(J=8.5 \mathrm{~Hz})$ for $\mathrm{H}-9$ and $\mathrm{H}-10$ of $\mathbf{5 a}$ and $\mathbf{5 b}$ suggested trans diaxial stereochemistry for the OAc groups at C-9 and C-10 of both isomers. The ${ }^{1} \mathrm{H}$ NMR (Table 2) and NOE data (Figure 3) established that 5a and $\mathbf{5 b}$ had the same relative configurations at C-6, C-9 and $\mathrm{C}-10$, confirming that these two isomers differed from each other only in their configuration at the spiro center (C-5). Regiospecific reduction of the carbonyl group of the enone 
moieties of the diacetates $\mathbf{5 a}$ and $\mathbf{5 b}$ with $\mathrm{NaBH}_{4} / \mathrm{CeCl}_{3}$ yielded 9,10-

diacetyldihydrooxaspirol B isomers $\mathbf{6 a}$ and $\mathbf{6 b}$ as the major products, which on acetylation ( $\mathrm{Ac}_{2} \mathrm{O}$ /pyridine) afforded 4,9,10-triacetyldihydrooxaspirol $\mathrm{B}$ isomers $\mathbf{7 a}$ and $\mathbf{7 b}$, respectively (Scheme 2). Because 1,2-reduction of enones with $\mathrm{NaBH}_{4} / \mathrm{CeCl}_{3}$ has been reported to be nonstereospecific when the $\mathrm{C}=\mathrm{C}$ bond of the enone is exocyclic, each of the diacetates (5a and $\mathbf{5 b}$ ) should have yielded two products. The formation of only one enol from each of these suggested that the configuration of the spiro-center (C-5) may have had some influence on the hydride addition to the carbonyl group at $\mathrm{C}-4$ during this reduction. This was supported by the ${ }^{1} \mathrm{H}$ NMR spectroscopic data for the triacetates $\mathbf{7 a}$ and $\mathbf{7 b}$, which showed major differences for $\mathrm{H}-4\left[\delta_{\mathrm{H}} 5.99 \mathrm{dd}(J=3.1\right.$ and $2.3 \mathrm{~Hz})$ for $7 \mathbf{a}$ and $6.44 \mathrm{t}(J=2.3 \mathrm{~Hz})$ for 7b], indicating that the OAc group at C-4 of $\mathbf{7 a}$ and $\mathbf{7 b}$ had opposite configurations. Comparison of the ${ }^{1} \mathrm{H}$ and ${ }^{13} \mathrm{C}$ NMR spectroscopic data of the triacetates $(\mathbf{7 a}$ and $\mathbf{7 b})$ with those of 4,9,10-triacetyloxaspirol A (1a) with defined stereochemistry at C-4, C-5, C-6, C-9 and C-10 (see above) suggested that $\mathbf{7 a}$ and $\mathbf{7 b}$ were different from 1a. Thus, the above data for $\mathbf{7 a}$ and $\mathbf{7 b}$ was not helpful in determining configurations at the spiro center (C-5) and/or the newly introduced chiral center (C-4) of these triacetates.

In an attempt to obtain additional information on absolute configuration of oxaspirol B (2), use of the modified Mosher's ester method was investigated. Thus, treatment of 2 with $(R)$ MTPA-Cl afforded its ( $S$ )-MTPA esters $8 \mathbf{a}$ and $9 \mathbf{a}$ which were separable by preparative thinlayer chromatography (TLC, Scheme 2). The ${ }^{1} \mathrm{H}$ NMR data of 8a and 9a (see Experimental Section) revealed that the esterification has taken place exclusively at OH-9. It is possible that the intramolecular H-bonding between $\mathrm{OH}-10$ and the ester carbonyl group prevented the retro-aldol process allowing their separation by preparative TLC (Figure S13). Similarly, the two $(R)$-MTPA esters $\mathbf{8 b}$ and $\mathbf{9 b}$ were obtained by the treatment of $\mathbf{2}$ with $(S)$-MTPA-Cl followed by preparative TLC separation (Scheme 2). Analysis of the $\Delta \delta\left(\delta_{\mathrm{S}}-\delta_{\mathrm{R}}\right.$ ) values suggested $R$ configuration for C-9 of both isomers of oxaspirol B (Figure 4), and the coupling constant $(J=8.6 \mathrm{~Hz})$ for $\mathrm{H}-9$ and $\mathrm{H}-10$ of $\mathbf{8 b}$ and $\mathbf{9 b}$ suggested that these protons are trans diaxial in both isomers. Relative stereochemistry of each of the remaining chiral centers was determined with the help of ${ }^{1} \mathrm{H}$ NMR and NOEDIFF data for the Mosher's esters 8a and 9a (Figures S14 and S15). Irradiation of the signal at $\delta_{\mathrm{H}} 4.35(\mathrm{H}-10)$ of 8a during the NOEDIFF experiment led to enhancement of the signal at $\delta_{\mathrm{H}} 3.53(\mathrm{H}-6)$, suggesting that these two protons are cofacial. In a similar experiment with 9a, an enhancement of the signal at $\delta_{\mathrm{H}} 3.41(\mathrm{H}-6)$ was observed upon irradiation of the signal at $\delta_{\mathrm{H}}$ 4.32 (H-10), suggesting that $\mathrm{H}-6$ and $\mathrm{H}-10$ in $9 \mathbf{a}$ are also cofacial. Thus, the absolute configurations at C-6, C-9, and C-10 in both isomers of oxaspirol B were determined as $6 R$, $9 R$, and $10 R$. However, all the above approaches were not helpful in assigning the absolute configuration of the spiro center (C-5) of any of the separable isomers of oxaspirol B derivatives (5a and $5 \mathbf{b}, 6 \mathbf{a}$ and $6 \mathbf{b}, 7 \mathbf{a}$ and $7 \mathbf{b}, 8 \mathbf{a}$ and $8 \mathbf{b}$, and $9 \mathbf{a}$ and $9 \mathbf{b}$ ).

Because absolute configurations at C-6, C-9, and C-10 of oxaspirol B (2) were determined to be the same as those of oxaspirol A (1) (see above), it was of interest to investigate if the reduction of the carbonyl group of the enone moiety of $\mathbf{2}$ would yield a product with the same configuration at C-4 and C-5 as those of $\mathbf{1}$. Thus, treatment of oxaspirol B (2) with $\mathrm{NaBH}_{4} / \mathrm{CeCl}_{3}$ afforded a mixture of two triols $\mathbf{1 0 a}$ and $\mathbf{1 0 b}$ (Scheme 2) in the ratio of ca. 1:1 
as indicated by the ${ }^{1} \mathrm{H}$ NMR spectrum (Figure S16). As noted above, regiospecific 1,2reduction of enones with $\mathrm{NaBH}_{4}$ in the presence of $\mathrm{CeCl}_{3}$ has been reported to be nonstereospecific when the $\mathrm{C}=\mathrm{C}$ bond of the enone is exocyclic; this reduction should have yielded four products, two alcohols from each oxaspirol B isomer. Formation of only two products in this reaction suggested that configuration of the spiro center (C-5) of each isomer of oxaspirol B (2a and $\mathbf{2 b}$ ) had influenced the hydride addition to the carbonyl carbon during this reduction, similar to that observed for $\mathbf{5 a}$ and $\mathbf{5 b}$ (see above). The mechanism of this reaction presumably involved a boron complex formed between the hydroxy group $\beta$ to the carbonyl carbon and delivering the hydride ion from the same side of the boron complex (Figure S17). Because attempted separation of the above triols (dihydrooxaspirol B isomers) 10a and 10b by chromatographic methods including chiral HPLC failed, the product mixture was treated with $\mathrm{Ac}_{2} \mathrm{O}$ /pyridine and the resulting triacetates (4,9,10-triacetyldihydrooxaspirol B isomers) were separated by chiral HPLC. The spectroscopic data [one-dimensional (1D) and two-dimensional (2D) NMR and lowresolution mass spectrometry] of one of these triacetates was found to be identical with 4,9,10-triacetyloxaspirol A (1a, see above) and the other with 7b obtained from oxaspirol B diacetate (5b) (Scheme 2). The foregoing evidence confirmed that the structure of the oxaspirol $\mathrm{B}$ isomer corresponding to $\mathbf{2 a}[(5 R)$-oxaspirol $\mathrm{B}]$ as $(5 R, 6 R, 9 R, 10 R)$-6-(hepta- $1 E$, $3 E$-dien)yl-9,10-dihydroxy-2-oxaspiro[4,5]dec-3(11),7-dien-1,4-dione. In a NOEDIFF experiment with the triacetate $7 \mathbf{b}$, the signal due to $\mathrm{H}-4\left(\delta_{\mathrm{H}} 6.44\right)$ was not enhanced upon irradiation of either $\mathrm{H}-6\left(\delta_{\mathrm{H}} 3.49\right)$ or $\mathrm{H}-10\left(\delta_{\mathrm{H}} 5.67\right)$ but enhanced each other, indicating that the configuration at $\mathrm{C}-5$ of $\mathbf{7 b}$ was the opposite to that of $\mathbf{1 a}$. Irradiation of signal due to H-4 caused an enhancement of the signal due to $\mathrm{H}-9\left(\delta_{\mathrm{H}} 5.48\right)$, suggesting that these two protons in $\mathbf{7 b}$ are cofacial (Figure 3). Thus, the absolute configuration of both C-4 and C-5 in $\mathbf{7 b}$ were determined as $S$. Because the configurations of both isomers of $\mathbf{2}$ were previously determined as $6 R, 9 R$, and $10 R$ (see above), the structure of the corresponding oxaspirol $\mathrm{B}$ isomer [(5S)-oxaspirol B] was established as $(5 S, 6 R, 9 R, 10 R)$-6-(hepta-1E,3E-dien)yl-9,10dihydroxy-2-oxaspiro[4,5]dec-3(11),7-dien-1,4-dione (2b).

Comparison of the ${ }^{1} \mathrm{H}$ and ${ }^{13} \mathrm{C}$ NMR spectroscopic data of $\mathbf{3}$ (Table 1) with those reported for other known oxaspirols suggested that it was identical with oxaspirol $\mathrm{C}$ for which only the planar structure has been reported. Thus, the absolute stereochemistry of $\mathbf{3}$ was determined by the application of the modified Mosher's ester method in combination with analysis of the NOEDIFF data. Treatment of $\mathbf{3}$ with $(R)$ - and (S)-MTPA-Cl afforded its $(S)$ and $(R)$-MTPA monoesters $\mathbf{3 a}$ and $\mathbf{3 b}$, respectively, and their ${ }^{1} \mathrm{H}$ NMR spectra suggested that the esterification had occurred exclusively at 9-OH. Analysis of the $\Delta \delta\left(\delta_{\mathrm{S}}-\delta_{\mathrm{R}}\right)$ value of these two esters revealed the absolute configuration of C-9 of $\mathbf{3}$ as $R$ (Figure 4). Irradiation of the signal at $\delta_{\mathrm{H}} 4.14$ (H-9) during a NOEDIFF experiment of 3 (in DMSO- $d_{6}$ ) enhanced the signal at $\delta_{\mathrm{H}} 4.02$ (H-10) suggesting that these two protons were on the same side of the molecule (Figure 3). A relatively small coupling constant $(J=4.1 \mathrm{~Hz})$ between H-9 and H-10 along with the investigation of the energy-minimized Chembio3D structure (Figure 3) determined that $\mathrm{H}-9$ of $\mathbf{3}$ was axially oriented and $\mathrm{H}-10$ had an equatorial orientation, suggesting that $\mathrm{OH}-9$ also had a $\beta$ orientation. Irradiation of the signal due to $\mathrm{H}-10 a$ enhanced signals at $\delta_{\mathrm{H}} 5.13(\mathrm{H}-4), 5.71(\mathrm{H}-8)$, and $5.31(\mathrm{OH}-10)$, suggesting that OH-4 had a $\beta$ orientation. Enhancement of the signals at $\delta_{\mathrm{H}} 5.17(\mathrm{OH}-4), 5.52(\mathrm{H}-7)$, and 
$5.95(\mathrm{H}-13)$ on irradiation of the signal at $\delta_{\mathrm{H}} 3.22(\mathrm{H}-6)$ confirmed that the side-chain of 3 was $a$ oriented as in oxaspirols A and $\mathrm{B}$. The foregoing data established the structure of oxaspirol $\mathrm{C}$ as $(4 R, 5 R, 6 R, 9 R, 10 S)$-6-(hepta-1,3-dien)yl-4,9,10-trihydroxy-2oxaspiro[4,5]dec-3-(11),7-dien-1-one (3, Figure 1).

The 1D and 2D NMR data of 4 (Table 1) indicated that, as in other oxaspirols, it also possessed the 2-oxaspiro[4,5]dec-7-ene skeleton with the same alkyl side-chain at C-6, but it was not identical with oxaspirols A-C (1-3) and was therefore named oxaspirol D. The ${ }^{1} \mathrm{H}$ and ${ }^{13} \mathrm{C}$ NMR data of 4 (Table 1) also indicated the absence of the exocyclic 3(11)-double bond found in 1-3. Instead, 4 had a dioxygenated carbon (C-3; $\left.\delta_{\mathrm{C}} 111.4\right)$ and a methyl group $\left[\mathrm{CH}_{3}-11 ; \delta_{\mathrm{H}} 1.64(S), \delta_{\mathrm{C}} 15.5\right]$, suggesting that this $\mathrm{O}-\mathrm{C}=\mathrm{CH}_{2}$ moiety has undergone hydration leading to a $\mathrm{O}-\mathrm{C}(\mathrm{OH})-\mathrm{CH}_{3}$ moiety in 4 . Detailed analysis of its ${ }^{1} \mathrm{H}$ and ${ }^{13} \mathrm{C}$ NMR data with the help of HSQC data indicated that the planar structure of the remaining portion of $\mathbf{4}$ was similar to those of $\mathbf{1}$ and $\mathbf{3}$ (Table 1). Treatment of oxaspirol D (4) with $(R)$ - and $(S)$-MTPA-Cl provided $(S)$-and $(R)$-MTPA monoesters $\mathbf{4 a}$ and $\mathbf{4 b}$, respectively, and their ${ }^{1} \mathrm{H}$ NMR spectra suggested that the esterification had occurred exclusively at OH-9 as for other oxaspirols. Analysis of the $\Delta \delta$ value $\left(\delta_{S}-\delta_{R}\right)$ revealed $R$ absolute configuration for C-9 $(\mathrm{OH}-9 \beta)$ (Figure 4). The configurations of the remaining chiral centers of 4 were determined on the basis of coupling constant data (Table 1) and NOE correlations (Figure 3). Relatively large coupling constant $(J=8.4 \mathrm{~Hz})$ for $\mathrm{H}-9$ and $\mathrm{H}-10$ suggested that these two protons had a trans diaxial relationship and hence $\mathrm{OH}-10$ should have an $a$ orientation. Irradiation of the signal at $\delta_{\mathrm{H}} 4.07(\mathrm{H}-10 \beta)$ enhanced that at $3.26(\mathrm{H}-6)$, suggesting that these protons were on the same face of the molecule. Irradiation of $\mathrm{CH}_{3}-11\left(\delta_{\mathrm{H}} 1.66\right)$ and $\mathrm{H}-6 \beta\left(\delta_{\mathrm{H}} 3.26\right)$ enhanced $\mathrm{H}-4 a\left(\delta_{\mathrm{H}} 4.24\right)$, indicating that these protons were $a$ oriented. Thus, the structure of oxaspirol D was established as $(3 S, 4 R, 5 R, 6 R, 9 R, 10 R)$-6-(hepta-1,3-dien)yl-3,4,9,10tetrahydroxy-3-methyl-2-oxaspiro[4,5]dec-7-en-1-one (4, Figure 1).

All natural oxaspirols encountered were evaluated for their ability to inhibit p97 using the malachite green-based ATPase assay, and only oxaspirol B (2) which contained an enone moiety showed activity. A dose-response study revealed that 2 had an $\mathrm{IC}_{50}$ of $31.2 \pm 3.0 \mu \mathrm{M}$ (Figure 2B). Intriguingly, the diacetates $\mathbf{5 a}$ and $\mathbf{5 b}$ of oxaspirol B (Scheme 2) were found to be inactive up to $200 \mu \mathrm{M}$, suggesting the requirement of other structural features (e.g., free $\mathrm{OH}$ group at $\mathrm{C}-9$ and/or C-10) in $\mathbf{2}$ for its activity in addition to the enone moiety and arguing for a specific mode of interaction with p97. Because many enones are known to exert their biological activities by acting as Michael acceptors of biological thiols and there are 12 cysteines in p97 including two in the ATP-binding sites (C209 in D1 and C522 in D2), cysteineless p97 (p97-cys0) was generated using a modified QuickChange procedure. Interestingly, oxaspirol B (2) did not inhibit p97-cys0 even at $200 \mu \mathrm{M}$ (Figure 6A), indicating that the activity was dependent on a possible covalent modification of cysteines and/or a specific steric requirement. To test this, wt-p97 (wildtype-p97) was incubated with 2 followed by dialysis to remove unbound $\mathbf{2}$. No inhibition of p97 was evident after extensive dialysis, suggesting that the observed inhibitory activity of $\mathbf{2}$ was due to its reversible binding to p97 (Figure 6B). Because oxaspirol B (2) was discovered in an ATPase inhibition screen and it had no inhibitory activity for $\mathrm{p} 97$-cys0, the possibility that it may be binding to one of the two ATP-binding pockets was next considered. To investigate this, 
Cys209 and Cys522 in p97 were converted to the single mutant alanine or serine mutants as described previously. Because 2 showed similar inhibitory activity for both these p97 mutants, the alanine mutants (Cys209a and Cys522A) were selected for further investigation. Interestingly, for both these p97 mutants the $\mathrm{IC}_{50}$ values were found to be similar to that of wt-p97 (Figure 6A), suggesting that 2 was not binding in the ATP-pockets and was not ATP-competitive. To further explore this, the effect of ATP concentration on $\mathrm{IC}_{50}$ of p97 inhibition of $\mathbf{2}$ was investigated and was found to have no effect (data not shown), confirming that $\mathbf{2}$ was a reversible, non-ATP competitive inhibitor of p97. Specificity of oxaspirol B (2) was evaluated next by investigating its ability to inhibit three ATP-utilizing macro-molecular systems, namely, the chaperonin GroEL, the type I AAA+ chaperone ClpX, and the type II AAA $+N$-ethylmaleimide sensitive factor (NSF). NSF is an AAA+ protein with the highest homology to $\mathrm{p} 97$. Remarkably, 2 showed specificity to only p97 with no effect on GroEL, ClpX, or NSF at concentrations up to $200 \mu \mathrm{M}$ (Figure 6C). Finally, the p97 inhibitory activity of oxaspirol B (2) was evaluated in two cell-based assays that were previously used for this purpose.' These assays utilized (i) HEK293 cells stably expressing a $\mathrm{Ub}^{\mathrm{G} 76} \mathrm{~V}_{\mathrm{GFP}}$ fusion protein (G76 V mutation prevents proteolysis of the ubiquitin) to measure the ubiquitin fusion degradation (UFD) pathway and (ii) HEK293 cells stably expressing a secretory protein [T-cell receptor $a$ (TCR- $a$ )] fused to GFP to report on the ERAD pathway. Because both assays took advantage of the requirement of $\mathrm{p} 97$ for the degradation of the substrates involved, inhibition of p97 would lead to a higher number of fluorescent cells quantifiable using fluorescence-activated cell sorting (FACS).' In these cellbased assays, oxaspirol C (3) had no effect, but oxaspirol B (2) showed a dose-dependent inhibition of GFP fluorescence loss, establishing that it was capable of inhibiting p97 in a cellular context (Figure 7). It is noteworthy that the level of inhibition was similar to that observed for other p97 ATPase inhibitors (DBeQ and ML240) reported in the literature.' Additional studies to define the precise mechanism of p97 inhibitory activity of $\mathbf{2}$ are currently ongoing and will be reported in due course.

\section{EXPERIMENTAL SECTION}

\section{General Experimental Procedures}

Optical rotations were measured with a JASCO Dip-370 digital polarimeter using $\mathrm{CHCl}_{3}$ or $\mathrm{MeOH}$ as solvent. Ultraviolet (UV) spectra were recorded on a Shimadzu UV-1601 UVvisible spectrophotometer. 1D and 2D NMR spectra were recorded with a Bruker Avance III 400 spectrometer at $400 \mathrm{MHz}$ for ${ }^{1} \mathrm{H}$ NMR and $100 \mathrm{MHz}$ for ${ }^{13} \mathrm{C}$ NMR, using residual solvent signal as internal reference. Chemical shift values $(\delta)$ are given in parts per million (ppm), and the coupling constants are in hertz. Low-resolution and high-resolution MS spectra were recorded on Shimadzu LCMS-QP8000 $a$ and Shimadzu LCMS-IT-TOF (225-07100-34) spectrometers, respectively. Whatman LRP-2 was used for reversed-phase (RP) column chromatography, and RP preparative TLC was performed on Merck RP-18 $\mathrm{F}_{254 \mathrm{~S}}$ precoated aluminum sheets. Analytical and preparative normal-phase TLC was performed on precoated $0.25 \mathrm{~mm}$ thick plates of silica gel $60 \mathrm{~F}_{254}$. Visualization of compounds on analytical TLC was performed by spraying with a solution of anisaldehyde in EtOH followed by heating. Preparative HPLC was performed on a Waters Delta Prep 400 preparative chromatography system equipped with a Waters 996 photodiode array detector 
and a Waters Prep LC controller utilizing Empower Pro software. RP and chiral HPLC separations were carried out using Phenomenex Luna $5 \mu \mathrm{m}, \mathrm{C}_{18}, 250 \times 10 \mathrm{~mm}$ and Chiralcel OD-R, $250 \times 4.6 \mathrm{~mm}$ columns. When necessary, MM2 energy minimizations of all possible conformers were carried out using Chembio3D Ultra 13.0 of CambridgeSoft Corp.

\section{Fungal Isolations}

In March 2008, apparently healthy thalli of Parmotrema tinctorum and Cladonia evansii were collected in a pine-dominated forest at Archbold Biological Station in Florida, United States $\left(27^{\circ} 11^{\prime} 19^{\prime \prime} \mathrm{N}, 81^{\circ} 20^{\prime} 15^{\prime \prime} \mathrm{W}\right.$, ca. 35 m.a.s.l.) as part of a larger study of endolichenic fungal diversity. Each thallus was washed in tap water; surface-sterilized by agitating sequentially in $95 \% \mathrm{EtOH}$ for $30 \mathrm{~s}, 0.5 \% \mathrm{NaOCl}$ for $2 \mathrm{~min}$, and $70 \% \mathrm{EtOH}$ for $2 \mathrm{~min}$; and then cut into 96 segments (each ca. $2 \mathrm{~mm}^{2}$ ). Segments were surface-dried under sterile conditions and then placed individually onto $2 \%$ malt extract agar in $1.5 \mathrm{~mL}$ microcentrifuge tubes. Tubes were sealed with Parafilm and incubated under ambient light/dark condition at room temperature (ca. $21.5^{\circ} \mathrm{C}$ ). Emergent fungi were isolated into pure culture on $2 \%$ MEA, vouchered in sterile water, and deposited as living vouchers at the Robert L. Gilbertson Mycological Herbarium at the University of Arizona. The fungi used for the present study were isolate FL1375 from P. tinctorum and isolate FL1031 from C. evansii. Both have been accessioned at the Robert L. Gilbertson Mycological Herbarium (accessions FL1375 and FL1031, respectively).

\section{Identification of Fungal Isolates FL1375 and FL1031}

Total genomic DNA was isolated from fresh mycelium of each focal culture. Identification of strain FL1031 was carried out as follows. The nuclear ribosomal internal transcribed spacers and 5.8s gene (ITS rDNA; ca. 600 base pairs [bp]) and the first ca. $600 \mathrm{bp}$ of the nuclear ribosomal large subunit (LSU rDNA) were amplified as single fragment by PCR. Positive amplicons were sequenced bidirectionally as described previously. A consensus sequence was assembled, and basecalls were made by phred and phrap with orchestration by Mesquite, followed by manual editing in Sequencher (Gene Codes Corp.). Because the isolate did not produce diagnostic fruiting structures in culture, two methods were used to tentatively identify FL1031 using molecular sequence data. First, the LSU rDNA portion of the sequence was evaluated using the naïve Bayesian classifier for fungi available through the Ribosomal Database Project (http://rdp.cme.msu.edu/). The Bayesian classifier estimated placement within the Sordariomycetes with high support, but placement at finer taxonomic levels was not possible. Therefore, the entire sequence was compared against the GenBank database using BLAST. The top BLAST matches were primarily to unidentified endophytes, and occasionally to identified strains of Lecythophora (anamorph) and Coniochaeta (teleomorph; Coniochaetaceae, Coniochaetales, Sordariomycetes, Pezizomycotina, Ascomycota). To clarify the phylogenetic placement and taxonomic assignment of FL1031, the LSU rDNA portion of the sequence in a second BLAST search was used and the 70 top matches were downloaded. The resulting data set was aligned automatically in MUSCLE (http://www.ebi.ac.uk/Tools/msa/muscle/) with default parameters and adjusted manually in MacClade prior to analysis. The final data set consisted of 72 sequences and 330 characters, including the outgroup and a diversity of endophytic and endolichenic fungi previously identified as part of the Lecythophora-Coniochaeta complex.' The data set was then 
analyzed using maximum likelihood in GARLI employing the GTR+I+G model of evolution as determined by ModelTest, followed by a bootstrap analysis with 1000 replicates. The analysis unequivocally placed FL1031 with strong support within the LecythophoraConiochaeta complex, with affinity for Coniochaeta pulveracea (anamorph: Lecythophora sp.).

The taxonomic placement of FL1375 was then examined. The nuclear ribosomal internal transcribed spacers and $5.8 \mathrm{~s}$ gene (ITS rDNA; ca. 600 base pairs [bp]) were amplified by PCR and processed as described above. The top BLAST hit for FL1375 was FL1031, with $97 \%$ sequence identity and $100 \%$ coverage at the ITS rDNA locus. Subsequent analyses of the ITSrDNA portion of the sequence using a Lecythophora-Coniochaeta data set published previously confirmed placement within the complex. Together these analyses revealed that sequences of FL1031 and FL1375 were not identical to each other or to any previously recognized species of Lecythophora available in NCBI. In the absence of sexual structures, these were designated as strains Lecythophora sp. FL1031 and Lecythophora sp. FL1375 pending morphological description. Sequence data for Lecythophora sp. FL1031 and Lecythophora sp. FL1375 have been deposited in GenBank under accession numbers JQ760665.1 and JQ760993.1, respectively.

\section{Culturing and Isolation of Metabolites from Lecythophora sp. FL1375}

A seed culture of the fungal strain FL1375 grown on PDA for 2 weeks was used for inoculation. Fresh mycelium was scraped out and mixed with sterile water and filtered through a $100 \mu \mathrm{m}$ filter to separate spores and hyphal fragments from mycelia. Absorbance of the spore/hyphal fragment solution was measured and adjusted to between 0.3 and 0.5 . This solution was used to inoculate $10 \times 2.0 \mathrm{~L}$ Erlenmeyer flasks, each holding $1.0 \mathrm{~L}$ of potato dextrose broth (PDB) and incubated at $160 \mathrm{rpm}$ and $28{ }^{\circ} \mathrm{C}$ for 7 days. Mycelia were separated by filtration, and combined supernatant $(\mathrm{pH}$ 6.5) was neutralized $(\mathrm{pH} 7)$ with 1.0 $\mathrm{M} \mathrm{NaOH}$ and extracted with EtOAc $(3 \times 5 \mathrm{~L})$. EtOAc extracts were combined, washed with $\mathrm{H}_{2} \mathrm{O}$, dried over anhydrous $\mathrm{Na}_{2} \mathrm{SO}_{4}$, and evaporated under reduced pressure to give the crude extract ( $3.33 \mathrm{~g}$ ), which was found to be active in a Malachite green assay for p97 ATPase inhibitory activity. A portion $(500.0 \mathrm{mg})$ of this extract was subjected to sizeexclusion chromatography over a column of Sephadex LH-20 (30.0 g) prepared in hexanes$\mathrm{CH}_{2} \mathrm{Cl}_{2}$ (1:4) and eluted with hexanes- $\mathrm{CH}_{2} \mathrm{Cl}_{2}(1: 4,750 \mathrm{~mL}), \mathrm{CH}_{2} \mathrm{Cl}_{2}$-acetone $(3: 2,300$ $\mathrm{mL}), \mathrm{CH}_{2} \mathrm{Cl}_{2}$-acetone $(1: 4,100 \mathrm{~mL}), \mathrm{CH}_{2} \mathrm{Cl}_{2}-\mathrm{MeOH}(1: 1,50 \mathrm{~mL})$, and $\mathrm{MeOH}(100 \mathrm{~mL})$. A total of 103 fractions (12 mL each) were collected, and those having similar TLC profiles were combined to give 18 combined fractions [A (7.5 mg), B ( $9.9 \mathrm{mg}), \mathrm{C}(3.9 \mathrm{mg}), \mathrm{D}$ (7.8 $\mathrm{mg}), \mathrm{E}(9.2 \mathrm{mg}), \mathrm{F}(24.8 \mathrm{mg}), \mathrm{G}(3.4 \mathrm{mg}), \mathrm{H}(12.8 \mathrm{mg}), \mathrm{I}(7.9 \mathrm{mg}), \mathrm{J}$ (11.1 mg), K (180.3 $\mathrm{mg}$ ), L (16.3 mg), M (14.8 mg), N (17.0 mg), O (53.7 mg), P (11.0 mg), Q (33.3 mg), and R $(12.8 \mathrm{mg}$ ]. Of these fractions, only fraction $\mathrm{K}$ was found to be active in the $\mathrm{p} 97$ inhibitory assay (see Figure 2). A portion $(10.0 \mathrm{mg}$ ) of this fraction was purified by preparative TLC using $\mathrm{MeOH}-\mathrm{CH}_{2} \mathrm{Cl}_{2}$ (94:6) as the eluent to give oxaspirol B (2) (9.6 mg, $R_{\mathrm{f}}=0.49$ ). Preparative TLC purification of fraction $\mathrm{H}(11.5 \mathrm{mg})$ and fraction I $(7.9 \mathrm{mg})$ [eluent: $\mathrm{CH}_{2} \mathrm{Cl}_{2}-\mathrm{MeOH}$ (95:5)] afforded oxaspirol D (4) (3.8 mg, $\left.R_{\mathrm{f}}=0.42\right)$ and oxaspirol C (3) (1.1 $\left.\mathrm{mg}, R_{\mathrm{f}}=0.53\right)$, respectively. 
A second culture of Lecythophora sp. FL1375 was prepared and processed as above to obtain an additional quantity of the EtOAc extract $(1.47 \mathrm{~g})$. A portion $(832.0 \mathrm{mg})$ of this extract was chromatographed over a column of silica gel $(27.0 \mathrm{~g})$ prepared in hexane-EtOAc $(8: 2)$ and eluted with hexanes containing increasing amounts of EtOAc followed by EtOAc. A total of 80 fractions were collected, and those having similar TLC profiles were combined to give 15 combined fractions [ $F_{1}(2.4 \mathrm{mg}), F_{2}(3.2 \mathrm{mg}), F_{3}(2.1 \mathrm{mg}), F_{4}(7.3 \mathrm{mg}), F_{5}(146.2$ $\mathrm{mg}), \mathrm{F}_{6}(6.2 \mathrm{mg}), \mathrm{F}_{7}(8.2 \mathrm{mg}), \mathrm{F}_{8}(150.5 \mathrm{mg}), \mathrm{F}_{9}(42.8 \mathrm{mg}), \mathrm{F}_{10}(36.0 \mathrm{mg}), \mathrm{F}_{11}(72.8 \mathrm{mg})$, $\mathrm{F}_{12}(29.9 \mathrm{mg}), \mathrm{F}_{13}(50.4 \mathrm{mg}), \mathrm{F}_{14}(34.4 \mathrm{mg})$, and $\left.\mathrm{F}_{15}(144.8 \mathrm{mg})\right]$. Fraction $\mathrm{F}_{5}(146.2 \mathrm{mg})$ was purified by RP-HPLC using $45 \%$ aqueous $\mathrm{CH}_{3} \mathrm{CN}$ containing $0.1 \%$ TFA to give oxaspirol C (3) $\left(10.1 \mathrm{mg}, t_{\mathrm{R}}=25.0 \mathrm{~min}\right)$ and oxaspirol B (2) $\left(35.4 \mathrm{mg}, t_{\mathrm{R}}=28.0 \mathrm{~min}\right)$. Fraction $\mathrm{F}_{9}$ contained only oxaspirol D (4) $(42.8 \mathrm{mg})$. Fraction $\mathrm{F}_{8}(150.5 \mathrm{mg})$ was chromatographed over a column of silica gel (3.8 g) prepared in $\mathrm{CH}_{2} \mathrm{Cl}_{2}-\mathrm{MeOH}(96: 4)$ and eluted with $\mathrm{CH}_{2} \mathrm{Cl}_{2}-\mathrm{MeOH}$ (96:4), $\mathrm{CH}_{2} \mathrm{Cl}_{2}-\mathrm{MeOH}$ (95:5), $\mathrm{CH}_{2} \mathrm{Cl}_{2}-\mathrm{MeOH}$ (94:6), $\mathrm{CH}_{2} \mathrm{Cl}_{2}-$ $\mathrm{MeOH}$ (93:7), followed by $\mathrm{CH}_{2} \mathrm{Cl}_{2}-\mathrm{MeOH}$ (90:10) to give 44 subfractions. These were combined to give 12 major subfractions $\left[\mathrm{F}_{8 \mathrm{~A}}(4.6 \mathrm{mg}), \mathrm{F}_{8 \mathrm{~B}}(10.8 \mathrm{mg}), \mathrm{F}_{8 \mathrm{C}}(10.7 \mathrm{mg}), \mathrm{F}_{8 \mathrm{D}}\right.$ (3.6 mg), $\mathrm{F}_{8 \mathrm{E}}(36.1 \mathrm{mg}), \mathrm{F}_{8 \mathrm{~F}}(7.8 \mathrm{mg}), \mathrm{F}_{8 \mathrm{G}}(2.4 \mathrm{mg}), \mathrm{F}_{8 \mathrm{H}}(3.4 \mathrm{mg}), \mathrm{F}_{8 \mathrm{I}}(2.3 \mathrm{mg}), \mathrm{F}_{8 \mathrm{~J}}(1.2$ $\mathrm{mg}), \mathrm{F}_{8 \mathrm{~K}}(6.6 \mathrm{mg})$, and $\left.\mathrm{F}_{8 \mathrm{~L}}(2.7 \mathrm{mg})\right]$ of which fraction $\mathrm{F}_{8 \mathrm{E}}$ contained pure oxaspirol $\mathrm{D}(\mathbf{4})$.

\section{Culturing and Isolation of Metabolites from Lecythophora sp. FL1031}

A seed culture of Lecythophora sp. (FL1031) grown on PDA for 2 weeks was used for inoculation. Fresh mycelium was scraped out and mixed with sterile water and filtered through a $100 \mu \mathrm{m}$ filter to separate spores and hyphal fragments from mycelia. Absorbance of the spore/hyphal fragment solution was measured and adjusted to between 0.3 and 0.5 . This solution was used to inoculate $1 \times 2.0 \mathrm{~L}$ Erlenmeyer flask holding $1.0 \mathrm{~L}$ of the medium (PDB) incubated at $160 \mathrm{rpm}$ and $28{ }^{\circ} \mathrm{C}$. On day 7, mycelia were separated by filtration, and the filtrate was extracted with EtOAc $(3 \times 500 \mathrm{~mL})$. The combined EtOAc extracts were washed with $\mathrm{H}_{2} \mathrm{O}$, dried over anhydrous $\mathrm{Na}_{2} \mathrm{SO}_{4}$, and evaporated under reduced pressure to give the crude EtOAc extract $(127.4 \mathrm{mg})$. A portion $(49.0 \mathrm{mg})$ of this extract was subjected

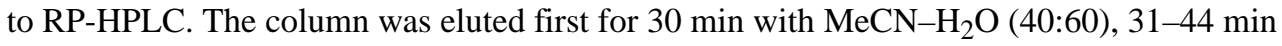
with $\mathrm{MeCN}-\mathrm{H}_{2} \mathrm{O}$ (50:50), 45-48 min with $\mathrm{MeCN}-\mathrm{H}_{2} \mathrm{O}$ (60:40), and 49-60 min with $\mathrm{MeCN}$ to give 13 crude fractions [ $\mathrm{F}_{1}(2.00-14.50 \mathrm{~min}, 8.7 \mathrm{mg}), \mathrm{F}_{2}(14.50-16.42 \mathrm{~min}, 0.9 \mathrm{mg}), \mathrm{F}_{3}$ (16.42-19.93 min, $0.9 \mathrm{mg}), \mathrm{F}_{4}(19.93-23.00 \mathrm{~min}, 0.4 \mathrm{mg}), \mathrm{F}_{5}(23.00-24.75 \mathrm{~min}, 1.3 \mathrm{mg}), \mathrm{F}_{6}$ (24.50-27.60 min, $0.7 \mathrm{mg}), \mathrm{F}_{7}(27.60-30.67 \mathrm{~min}, 20.7 \mathrm{mg}), \mathrm{F}_{8}(30.67-40.65 \mathrm{~min}, 1.4 \mathrm{mg}$ ), $\mathrm{F}_{9}$ (40.65-41.74 min, $\left.1.1 \mathrm{mg}\right), \mathrm{F}_{10}(41.74-43.61 \mathrm{~min}, 3.1 \mathrm{mg}), \mathrm{F}_{11}$ (43.61-46.02 min, 0.7 $\mathrm{mg}), \mathrm{F}_{12}(46.02-47.78 \mathrm{~min}, 2.7 \mathrm{mg})$, and $\left.\mathrm{F}_{13}(47.78-60.00 \mathrm{~min}, 4.1 \mathrm{mg})\right]$. A portion of fraction $\mathrm{F}_{7}\left(4.0 \mathrm{mg}\right.$ ) was further purified by preparative TLC (eluent: $\mathrm{CH}_{2} \mathrm{Cl}_{2}$-2-propanol 85:15) to give oxaspirol A (1) $(2.0 \mathrm{mg})$. Fractions $\mathrm{F}_{10}$ and $\mathrm{F}_{12}$ contained mainly oxaspirol C (3) (3.1 mg) and oxaspirol B (2) (2.7 mg), respectively. The identities of oxaspirols B (2) and C (3) were confirmed by comparison (TLC, LR-MS, and NMR) with those obtained above from Lecythophora sp. FL1375.

Oxaspirol A (1)—colorless film; ${ }^{1} \mathrm{H}$ and ${ }^{13} \mathrm{C}$ NMR data, see Table 1 . These data were comparable with those reported for oxaspirol A; APCI-MS (+) mode $m / z 289\left[\mathrm{M}+\mathrm{H}-\mathrm{H}_{2} \mathrm{O}\right]^{+}$, $271\left[\mathrm{M}+\mathrm{H}-2 \mathrm{H}_{2} \mathrm{O}\right]^{+}$APCI-MS (-) mode $\mathrm{m} / \mathrm{z} 305[\mathrm{M}-\mathrm{H}]^{-}$.

J Nat Prod. Author manuscript; available in PMC 2017 February 26. 
Oxaspirol B (2)—pale yellow, amorphous solid; $[\alpha]_{\mathrm{D}}^{25}-99$ (c 0.1, MeOH); UV (EtOH) $\lambda_{\max }(\log \varepsilon) 228(3.34) \mathrm{nm} ;{ }^{1} \mathrm{H} \mathrm{NMR}\left(\mathrm{CDCl}_{3}, 400 \mathrm{MHz}\right) \delta 6.04$ and 5.95 (1H each, dd, $J=$ 15.2, 9.2, H-13), 5.79 (2H, m, H-14), 5.58 (2H, m, H-15), 5.67 (2H, m, H-8), 5.40 (2H, ddd, $J=10.2,4.2,2.2 \mathrm{~Hz}, \mathrm{H}-7), 5.32$ and 5.28 (1H each, d, $J=2.8 \mathrm{~Hz}, \mathrm{H}-11 \mathrm{a}), 5.16$ and $5.06(1 \mathrm{H}$ each, dd, $J=15.2,9.2 \mathrm{~Hz}, \mathrm{H}-12$ ), 4.97 and 4.96 (1H each, d, $J=2.8 \mathrm{~Hz}, \mathrm{H}-11 \mathrm{~b}$ ), 4.51 and 4.46 (1H each, m, H-9), 3.90 and 3.88 (1H each, d, $J=8.6 \mathrm{~Hz}, \mathrm{H}-10), 3.46$ and $3.36(1 \mathrm{H}$ each, m, H-6), 1.93 (4H, q, $\left.J=7.2 \mathrm{~Hz}, \mathrm{H}_{2}-16\right), 1.29$ (4H, sextet, $J=7.2 \mathrm{~Hz}, \mathrm{H}_{2}-17$ ), 0.79 $\left(6 \mathrm{H}, \mathrm{t}, J=7.2 \mathrm{~Hz}, \mathrm{H}_{3}-18\right) ;{ }^{13} \mathrm{C} \mathrm{NMR}\left(\mathrm{CDCl}_{3}, 100 \mathrm{MHz}\right) \delta 196.8$ and $194.7(2 \times \mathrm{C}, \mathrm{C}-4)$, 172.6 and $169.6(2 \times \mathrm{C}, \mathrm{C}-1), 150.9$ and $150.3(2 \times \mathrm{C}, \mathrm{C}-3), 137.3$ and $137.1(2 \times \mathrm{CH}$, $\mathrm{C}-15), 136.0(2 \times \mathrm{CH}, \mathrm{C}-13), 129.1$ and $129.0(2 \times \mathrm{CH}, \mathrm{C}-8), 128.7$ and $128.6(2 \times \mathrm{CH}$, C-14), 127.8 and $127.3(2 \times \mathrm{CH}, \mathrm{C}-7), 124.1$ and $123.9(2 \times \mathrm{CH}, \mathrm{C}-12), 95.7$ and $95.5(2 \times$ $\left.\mathrm{CH}_{2}, \mathrm{C}-11\right), 74.7$ and $74.4(2 \times \mathrm{CH}, \mathrm{C}-10), 70.0$ and $69.6(2 \times \mathrm{CH}, \mathrm{C}-9), 59.4(2 \times \mathrm{C}, \mathrm{C}-5)$, 45.9 and $45.5(2 \times \mathrm{CH}, \mathrm{C}-6), 34.4\left(2 \times \mathrm{CH}_{2}, \mathrm{C}-16\right), 22.1\left(2 \times \mathrm{CH}_{2}, \mathrm{C}-17\right)$, and $13.6(2 \times$ $\left.\mathrm{CH}_{3}, \mathrm{C}-18\right)$. These data were comparable with those reported for oxaspirol B. APCI-MS (+) mode $\mathrm{m} / \mathrm{z} 305[\mathrm{M}+\mathrm{H}]^{+}, 287\left[\mathrm{M}+\mathrm{H}-\mathrm{H}_{2} \mathrm{O}\right]^{+}$, APCI-MS (-) mode $\mathrm{m} / \mathrm{z} 303[\mathrm{M}-\mathrm{H}]^{-}$.

Oxaspirol C (3)—colorless amorphous solid. $[\alpha]_{\mathrm{D}}^{25}-148(c 0.09, \mathrm{MeOH})$; UV (EtOH) $\lambda_{\max }(\log \varepsilon) 235$ (3.64) nm; ${ }^{1} \mathrm{H}$ and ${ }^{13} \mathrm{C}$ NMR data in DMSO- $d_{6}$, see Table 1. These data were consistent with those reported for oxaspirol C; APCI-MS (+) mode $m / z 289$ [M+H$\left.\mathrm{H}_{2} \mathrm{O}\right]^{+}$, APCI-MS (-) mode $m / z 305[\mathrm{M}-\mathrm{H}]^{-}$.

Oxaspirol D (4)—colorless gum. $[\alpha]_{\mathrm{D}}^{25}-78(c 0.2, \mathrm{MeOH})$; UV (EtOH) $\lambda_{\max }(\log \varepsilon) 233$ (2.78), 274 (0.97) $\mathrm{nm} ;{ }^{1} \mathrm{H}$ and ${ }^{13} \mathrm{C}$ NMR data, see Table 1; HR-ESI-TOFMS $m / z 347.1519$ $[\mathrm{M}+\mathrm{Na}]^{+}$(calcd for $\mathrm{C}_{17} \mathrm{H}_{24} \mathrm{NaO}_{6}, 347.1471$ ).

\section{General Procedure for the Preparation of $(S)$ - and (R)-MTPA Ester Derivatives of Oxaspirols A-D (1-4)}

The general procedure used for the preparation of $(S)$ - and $(R)$ - MTPA esters of 1-4 is illustrated below for oxaspirol A (1). To a solution of $\mathbf{1}(2.0 \mathrm{mg})$ in pyridine- $d_{5}(0.5 \mathrm{~mL})$ in an NMR tube $(5.0 \mathrm{~mm})$ was added $(R)$-MTPA-Cl $(4.0 \mu \mathrm{L})$, and the mixture was left at $25^{\circ} \mathrm{C}$ until the reaction was complete (progress monitored by ${ }^{1} \mathrm{H}$ NMR). The reaction mixture was transferred to a RB flask, and pyridine was removed azeotropically with EtOH under reduced pressure. The crude product thus obtained was purified by preparative TLC (silica gel) using EtOAc as eluent to give oxaspirol A (S)-MTPA ester (1b). A similar reaction of $\mathbf{1}$ with $(S)$-MTPA-Cl and purification of the product as above afforded oxaspirol A $(R)$-MTPA ester (1c). In contrast to oxaspirols A, C, and D, esterification of oxaspirol B (2) with $(R)$ and $(S)$-MTPA-chlorides gave two $(S)$-MTPA esters 8a and 9a and $(R)$-MTPA esters $\mathbf{8 b}$ and 9b, respectively. Assignments of ${ }^{1} \mathrm{H}$ NMR data of all MTPA ester derivatives were based on their ${ }^{1} \mathrm{H}-{ }^{1} \mathrm{H}$ COSY spectra.

(S)-MTPA Ester of Oxaspirol A (1b)— ${ }^{1} \mathrm{H} \mathrm{NMR}\left(400 \mathrm{MHz}, \mathrm{CDCl}_{3}\right) \delta 6.048(1 \mathrm{H}$, dd, $J=15.0,10.2 \mathrm{~Hz}, \mathrm{H}-13), 5.895(1 \mathrm{H}, \mathrm{m}, \mathrm{H}-14), 5.891(1 \mathrm{H}, \mathrm{m}, \mathrm{H}-9), 5.779(1 \mathrm{H}, \mathrm{m}, \mathrm{H}-7)$, $5.757(1 \mathrm{H}, \mathrm{m}, \mathrm{H}-8), 5.638(1 \mathrm{H}, \mathrm{dt}, J=15.1,6.9 \mathrm{~Hz}, \mathrm{H}-15), 5.389(1 \mathrm{H}, \mathrm{dd}, J=15.0,9.5 \mathrm{~Hz}$, H-12), 4.809 (1H, t, $J=2.7 \mathrm{~Hz}, \mathrm{H}-11 \mathrm{a}), 4.590(1 \mathrm{H}, \mathrm{t}, J=2.7 \mathrm{~Hz}, \mathrm{H}-11 \mathrm{~b}), 4.614(1 \mathrm{H}, \mathrm{br}$, 
H-4), $3.883(1 \mathrm{H}, \mathrm{d}, J=5.4 \mathrm{~Hz}, \mathrm{H}-10), 3.351(1 \mathrm{H}, \mathrm{br} \mathrm{dd}, J=9.5,1.9 \mathrm{~Hz}, \mathrm{H}-6), 2.004$ (2H, q, $J=7.4 \mathrm{~Hz}, \mathrm{H}-16), 1.361$ (2H, sextet, $J=7.4 \mathrm{~Hz}, \mathrm{H}-17), 0.861$ (3H, t, $J=7.4 \mathrm{~Hz}, \mathrm{H}-18$ ).

(R)-MTPA Ester of Oxaspirol A (1c)- ${ }^{1} \mathrm{H}$ NMR $\left(400 \mathrm{MHz}, \mathrm{CDCl}_{3}\right) \delta 6.069(1 \mathrm{H}$, dd, $J=15.1,10.2 \mathrm{~Hz}, \mathrm{H}-13), 5.932$ (1H, m, H-9), 5.895 (1H, m, H-14), 5.701 (1H, m, H-7), $5.680(1 \mathrm{H}, \mathrm{m}, \mathrm{H}-8), 5.645(1 \mathrm{H}, \mathrm{m}, \mathrm{H}-15), 5.392(1 \mathrm{H}, d d, J=15.0,9.4 \mathrm{~Hz}, \mathrm{H}-12), 5.094(1 \mathrm{H}$, br, H-4), 4.834 (1H, t, $J=2.6 \mathrm{~Hz}, \mathrm{H}-11 \mathrm{a}), 4.637$ (1H, t, $J=2.5 \mathrm{~Hz}, \mathrm{H}-11 \mathrm{~b}), 4.044$ (1H, d, $J=$ $5.8 \mathrm{~Hz}, \mathrm{H}-10), 3.402$ (1H, brdd, $J=9.5,2.3 \mathrm{~Hz}, \mathrm{H}-6), 2.006(2 \mathrm{H}, q, J=7.3 \mathrm{~Hz}, \mathrm{H}-16), 1.363$ $(2 \mathrm{H}$, sextet, $J=7.4 \mathrm{~Hz}, \mathrm{H}-17), 0.863(3 \mathrm{H}, t, J=7.3 \mathrm{~Hz}, \mathrm{H}-18)$.

(S)-MTPA Esters of Oxaspirol B (8a and 9a)-(S)-MTPA ester derivative 8a: ${ }^{1} \mathrm{H}$ NMR (400 MHz, $\left.\mathrm{CDCl}_{3}\right) \delta 6.120(1 \mathrm{H}, \mathrm{dd}, J=15.2,10.4 \mathrm{~Hz}, \mathrm{H}-13), 5.944(1 \mathrm{H}, \mathrm{m}, \mathrm{H}-9)$, $5.839(1 \mathrm{H}, \mathrm{dd}, J=15.6,10.4 \mathrm{~Hz}, \mathrm{H}-14), 5.770(1 \mathrm{H}, \mathrm{dt}, J=10.0,2.8 \mathrm{~Hz}, \mathrm{H}-7), 5.694(1 \mathrm{H}$, $\mathrm{dd}, J=15.6,6.8 \mathrm{~Hz}, \mathrm{H}-15), 5.633(1 \mathrm{H}, \mathrm{dt}, J=10.0,2.0 \mathrm{~Hz}, \mathrm{H}-8), 5.405(1 \mathrm{H}, \mathrm{d}, J=2.8 \mathrm{~Hz}$, H-11a), $5.118(1 \mathrm{H}, \mathrm{dd}, J=15.2,9.6 \mathrm{~Hz}, \mathrm{H}-12), 5.059(1 \mathrm{H}, \mathrm{d}, J=2.8 \mathrm{~Hz}, \mathrm{H}-11 \mathrm{~b}), 4.279(1 \mathrm{H}$, d, $J=8.0 \mathrm{~Hz}, \mathrm{H}-10), 3.522$ (1H, m, H-6), 1.997 (2H, m, H $\left.{ }_{2}-16\right), 1.358\left(2 \mathrm{H}, \mathrm{m}, \mathrm{H}_{2}-17\right)$, $0.853\left(3 \mathrm{H}, \mathrm{t}, J=7.6 \mathrm{~Hz}, \mathrm{H}_{3}-18\right)$. ( $S$ )-MTPA ester derivative 9a: ${ }^{1} \mathrm{H} \mathrm{NMR}\left(400 \mathrm{MHz}, \mathrm{CDCl}_{3}\right)$ $\delta 6.027(1 \mathrm{H}, \mathrm{dd}, J=14.8,10.4 \mathrm{~Hz}, \mathrm{H}-13), 5.959(1 \mathrm{H}, \mathrm{m}, \mathrm{H}-9), 5.867$ (1H, dd, $J=15.2,10.8$ $\mathrm{Hz}, \mathrm{H}-14), 5.753$ (1H, dt, $J=10.0,2.8 \mathrm{~Hz}, \mathrm{H}-7), 5.661(1 \mathrm{H}, \mathrm{dd}, J=15.6,6.8 \mathrm{~Hz}, \mathrm{H}-15)$, $5.633(1 \mathrm{H}, \mathrm{m}, \mathrm{H}-8), 5.397(1 \mathrm{H}, \mathrm{d}, J=2.8 \mathrm{~Hz}, \mathrm{H}-11 \mathrm{a}), 5.217(1 \mathrm{H}, \mathrm{dd}, J=14.8,9.2 \mathrm{~Hz}$, H-12), $5.065(1 \mathrm{H}, \mathrm{d}, J=2.8 \mathrm{~Hz}, \mathrm{H}-11 \mathrm{~b}), 4.245(1 \mathrm{H}, \mathrm{d}, J=8.0 \mathrm{~Hz}, \mathrm{H}-10), 3.408(1 \mathrm{H}, \mathrm{m}$, H-6), 1.996 (2H, m, $\left.\mathrm{H}_{2}-16\right), 1.355$ (2H, m, $\left.\mathrm{H}_{2}-17\right), 0.851$ (3H, t, $\left.J=7.6 \mathrm{~Hz}, \mathrm{H}_{3}-18\right)$.

(R)-MTPA Esters of Oxaspirol B (8b and 9b)—(R)-MTPA ester derivative $\mathbf{8 b}$ : ${ }^{1} \mathrm{H}$ NMR (400 MHz, CDCl $\left.)_{3}\right) 6.119(1 \mathrm{H}, \mathrm{dd}, J=15.2,10.4 \mathrm{~Hz}, \mathrm{H}-13), 5.929(1 \mathrm{H}, \mathrm{m}, \mathrm{H}-9)$, $5.840(1 \mathrm{H}, \mathrm{dd}, J=15.2,10.4 \mathrm{~Hz}, \mathrm{H}-14), 5.694(1 \mathrm{H}, \mathrm{dd}, J=15.6,6.8 \mathrm{~Hz} . \mathrm{H}-15), 5.670(1 \mathrm{H}$, dt, $J=10.0,3.6 \mathrm{~Hz}, \mathrm{H}-7), 5.598(1 \mathrm{H}, \mathrm{dt}, J=10.4,1.6 \mathrm{~Hz}, \mathrm{H}-8), 5.410(1 \mathrm{H}, \mathrm{d}, J=2.8 \mathrm{~Hz}$, H-11a), $5.117(1 \mathrm{H}, \mathrm{dd}, J=15.2,9.2 \mathrm{~Hz}, \mathrm{H}-12), 5.068(1 \mathrm{H}, \mathrm{d}, J=2.8 \mathrm{~Hz}, \mathrm{H}-11 \mathrm{~b}), 4.351(1 \mathrm{H}$, d, $J=8.0 \mathrm{~Hz}, \mathrm{H}-10), 3.534$ (1H, m, H-6), 1.997 (2H, m, H2-16), 1.359 (2H, m, H2-17), $0.854\left(3 \mathrm{H}, \mathrm{t}, J=7.6 \mathrm{~Hz}, \mathrm{H}_{3}-18\right)$. ( $R$ )-MTPA ester derivative 9b: ${ }^{1} \mathrm{H}$ NMR $(400 \mathrm{MHz}$, $\left.\mathrm{CDCl}_{3}\right) \delta 6.027(1 \mathrm{H}, \mathrm{dd}, J=15.2,10.4 \mathrm{~Hz}, \mathrm{H}-13), 5.946(1 \mathrm{H}, \mathrm{m}, \mathrm{H}-9), 5.868(1 \mathrm{H}, \mathrm{dd}, J=$ $15.2,10.4 \mathrm{~Hz}, \mathrm{H}-14), 5.661(1 \mathrm{H}, \mathrm{dd}, J=15.6,6.8 \mathrm{~Hz}, \mathrm{H}-15), 5.646(1 \mathrm{H}, \mathrm{dt}, J=10.0,3.6 \mathrm{~Hz}$, H-7), $5.599(1 \mathrm{H}, \mathrm{dt}, J=10.4,1.6 \mathrm{~Hz}, \mathrm{H}-8), 5.414(1 \mathrm{H}, \mathrm{d}, J=2.8 \mathrm{~Hz}, \mathrm{H}-11 \mathrm{a}), 5.214(1 \mathrm{H}, \mathrm{dd}$, $J=15.2,9.2 \mathrm{~Hz}, \mathrm{H}-12), 5.077(1 \mathrm{H}, \mathrm{d}, J=2.8 \mathrm{~Hz}, \mathrm{H}-11 \mathrm{~b}), 4.315(1 \mathrm{H}, \mathrm{d}, J=8.0 \mathrm{~Hz}, \mathrm{H}-10)$, $3.411(1 \mathrm{H}, \mathrm{m}, \mathrm{H}-6), 1.997\left(2 \mathrm{H}, \mathrm{m}, \mathrm{H}_{2}-16\right), 1.356\left(2 \mathrm{H}, \mathrm{m}, \mathrm{H}_{2}-17\right), 0.851(3 \mathrm{H}, \mathrm{t}, J=7.6 \mathrm{~Hz}$, $\left.\mathrm{H}_{3}-18\right)$.

(S)-MTPA Ester of Oxaspirol C (3a) - ${ }^{1} \mathrm{H}$ NMR (400 MHz, pyridine- $\left.d_{5}\right) \delta 6.460(1 \mathrm{H}$, m, H-9), 6.275 (1H, dd, $J=14.8 \mathrm{~Hz}, \mathrm{H}-13), 6.078(1 \mathrm{H}, \mathrm{m}, \mathrm{H}-14), 6.046(1 \mathrm{H}, \mathrm{m}, \mathrm{H}-7), 6.029$ $(1 \mathrm{H}, \mathrm{m}, \mathrm{H}-8), 5.898(1 \mathrm{H}, \mathrm{dd}, J=15.2, \mathrm{~Hz}, \mathrm{H}-12), 5.594(1 \mathrm{H}, \mathrm{m}, \mathrm{H}-15), 5.521(1 \mathrm{H}, \mathrm{t}, J=2.0$ $\mathrm{Hz}, \mathrm{H}-4), 5.033(1 \mathrm{H}, \mathrm{d}, J=4.4 \mathrm{~Hz}, \mathrm{H}-10), 4.959(1 \mathrm{H}, \mathrm{t}, J=2.4 \mathrm{H}-11 \mathrm{a}), 4.880(1 \mathrm{H}, \mathrm{t}, J=2.4$ $\mathrm{Hz}, \mathrm{H}-11 \mathrm{~b}), 4.085(1 \mathrm{H}, \mathrm{d}, J=8.4 \mathrm{~Hz}, \mathrm{H}-6), 1.915(2 \mathrm{H}, \mathrm{q}, J=7.2 \mathrm{~Hz}, \mathrm{H}-16), 1.251(2 \mathrm{H}, \mathrm{q}, J=$ $7.2 \mathrm{~Hz}, \mathrm{H}-17), 0.772(3 \mathrm{H}, \mathrm{t}, J=7.2 \mathrm{~Hz}, \mathrm{H}-18)$. 
(R)-MTPA Ester of Oxaspirol C (3b) - ${ }^{1} \mathrm{H}$ NMR $\left(400 \mathrm{MHz}\right.$, pyridine- $\left.d_{5}\right) \delta 6.549(1 \mathrm{H}$, m, H-9), 6.299 (1H, dd, $J=15.2 \mathrm{~Hz}, \mathrm{H}-13), 6.063(1 \mathrm{H}, \mathrm{dd}, 14.8 \mathrm{~Hz}, \mathrm{H}-14), 5.951(1 \mathrm{H}, \mathrm{m}$, H-7), 5.942 (1H, m, H-12), 5.923 (1H, m, H-8), 5.839 (1H, t, J=2.4 Hz, H-4), $5.576(1 \mathrm{H}$, $\mathrm{m}, \mathrm{H}-15), 5.107(1 \mathrm{H}, \mathrm{d}, J=4.4 \mathrm{~Hz}, \mathrm{H}-10), 4.966(1 \mathrm{H}, \mathrm{t}, J=2.0 \mathrm{H}-11 \mathrm{a}), 4.918(1 \mathrm{H}, \mathrm{t}, J=2.0$ Hz, H-11b), 4.156 (1H, d, $J=6.8 \mathrm{~Hz}, \mathrm{H}-6), 1.910(2 \mathrm{H}, \mathrm{q}, J=7.2 \mathrm{~Hz}, \mathrm{H}-16), 1.247$ (2H, q, $J$ $=7.2 \mathrm{~Hz}, \mathrm{H}-17), 0.779(3 \mathrm{H}, \mathrm{t}, J=7.2 \mathrm{~Hz}, \mathrm{H}-18)$.

(S)-MTPA Ester of Oxaspirol D (4a)- ${ }^{1} \mathrm{H}$ NMR $\left(400 \mathrm{MHz}, \mathrm{CDCl}_{3}\right) \delta 5.958(1 \mathrm{H}, \mathrm{m}$, $\mathrm{H}-13), 5.955$ (1H, m, H-14), 5.658 (1H, m, H-9), 5.645 (1H, m, H-7), 5.621 (1H, m, H-15), $5.518(1 \mathrm{H}$, brd, $J=10.7 \mathrm{~Hz}, \mathrm{H}-8), 5.387(1 \mathrm{H}, \mathrm{br}, \mathrm{H}-4), 5.338(1 \mathrm{H}, \mathrm{m}, \mathrm{H}-12), 4.976(1 \mathrm{H}, \mathrm{t}, J$ $=2.7 \mathrm{~Hz}, \mathrm{H}-11 \mathrm{a}), 4.751(1 \mathrm{H}, \mathrm{t}, J=2.5 \mathrm{~Hz}, \mathrm{H}-11 \mathrm{~b}), 4.454(1 \mathrm{H}, \mathrm{brdd}, J=8.3,2.5 \mathrm{~Hz}, \mathrm{H}-10)$, 3.250 (1H, m, H-6), 2.002 (2H, m, H-16), 1.359 (2H, sextet, $J=7.4 \mathrm{~Hz}, \mathrm{H}-17), 0.861$ (3H, t, $J=7.4 \mathrm{~Hz}, \mathrm{H}-18$ ).

(R)-MTPA Ester of Oxaspirol D (4b)—1 ${ }^{1} \mathrm{H}$ NMR $\left(400 \mathrm{MHz}, \mathrm{CDCl}_{3}\right) \delta 5.972(1 \mathrm{H}, \mathrm{m}$, H-13), 5.946 (1H, m, H-14), 5.653 (1H, m, H-9), $5.614(1 \mathrm{H}$, brd, $J=9.3 \mathrm{~Hz}, \mathrm{H}-7), 5.697$ (1H, br, H-8), 5.632 (1H, m, H-15), 5.347 (1H, d, $J=9.3 \mathrm{~Hz}, \mathrm{H}-12), 5.367$ (1H, br, H-4), $4.966(1 \mathrm{H}, \mathrm{t}, J=2.7 \mathrm{~Hz}, \mathrm{H}-11 \mathrm{a}), 4.733(1 \mathrm{H}, \mathrm{t}, J=2.6 \mathrm{~Hz}, \mathrm{H}-11 \mathrm{~b}), 4.362(1 \mathrm{H}, \mathrm{brdd}, J=8.8$, $3.5 \mathrm{~Hz}, \mathrm{H}-10), 3.254$ (1H, m, H-6), 2.002 (2H, m, H-16), 1.364 (2H, q, J= 7.4 Hz, H-17), $0.862(3 \mathrm{H}, \mathrm{t}, J=7.4 \mathrm{~Hz}, \mathrm{H}-18)$.

Acetylation of Oxaspirol A (1)-To a solution of oxaspirol A (1) $(1.9 \mathrm{mg})$ in pyridine $(0.5 \mathrm{~mL})$ was added $\mathrm{Ac}_{2} \mathrm{O}(0.2 \mathrm{~mL})$, and the mixture was stirred at $25^{\circ} \mathrm{C}$. After $6 \mathrm{~h}$ (TLC control), the reaction mixture solvent was evaporated under reduced pressure and residual pyridine was azeotrophed with EtOH to yield the crude product mixture which was purified by preparative TLC (silica gel) (eluent: $1 \% \mathrm{MeOH}$ in $\mathrm{CH}_{2} \mathrm{Cl}_{2}$, double elution) to give 4,9,10-triacetyloxaspirol A (1a) $(2.1 \mathrm{mg})$ as a colorless film; $[a]_{\mathrm{D}}{ }^{25}-304\left(c 1.2, \mathrm{CHCl}_{3}\right) ;{ }^{1} \mathrm{H}$ and ${ }^{13} \mathrm{C}$ NMR data, see Tables 2 and 3, respectively; APCI-MS (+) mode $m / z 373[\mathrm{M}+\mathrm{H}-$ $\mathrm{AcOH}]^{+}, 313[\mathrm{M}+\mathrm{H}-2 \mathrm{xAcOH}]^{+}, 253[\mathrm{M}+\mathrm{H}-3 \mathrm{xAcOH}]^{+}$.

Acetylation of Oxaspirol B (2)-To a solution of $2(6.1 \mathrm{mg})$ in pyridine $(0.3 \mathrm{~mL})$ was added $\mathrm{Ac}_{2} \mathrm{O}(0.3 \mathrm{~mL})$, and the mixture was stirred at $25^{\circ} \mathrm{C}$. After $16 \mathrm{~h}$, the reaction mixture solvent was evaporated under reduced pressure and residual pyridine was azeotrophed with EtOH to yield the crude product mixture which was purified by chiral HPLC [Chiralcel OD$\mathrm{R}, 250 \times 4.6 \mathrm{~mm}, \mathrm{MeOH}-\mathrm{H}_{2} \mathrm{O}(75: 25), 0.8 \mathrm{~mL} / \mathrm{min}$ ] to give 9,10-diacetyloxaspirol B isomers $5 \mathbf{a}\left(2.6 \mathrm{mg}, t_{\mathrm{R}}=35.0 \mathrm{~min}\right)$ and $\mathbf{5 b}\left(2.0 \mathrm{mg}, t_{\mathrm{R}}=40.10 \mathrm{~min}\right)$.

9,10-Diacetyloxaspirol B Isomer 5a-colorless film; $[\alpha]_{\mathrm{D}}^{25}-193\left(c 0.5, \mathrm{CHCl}_{3}\right) ;{ }^{1} \mathrm{H}$ and ${ }^{13} \mathrm{C}$ NMR data, see Tables 2 and 3, respectively; APCI-MS (+) mode $\mathrm{m} / z 329[\mathrm{M}+\mathrm{H}-$ $\mathrm{AcOH}]^{+}, 269[\mathrm{M}+\mathrm{H}-2 \mathrm{xAcOH}]^{+}$.

9,10-Diacetyloxaspirol B Isomer 5b-colorless film; $[\alpha]_{\mathrm{D}}^{25}-225\left(c 0.8, \mathrm{CHCl}_{3}\right) ;{ }^{1} \mathrm{H}$ and ${ }^{13} \mathrm{C}$ NMR data, see Tables 2 and 3, respectively; APCI-MS (+) mode $\mathrm{m} / \mathrm{z} 329[\mathrm{M}+\mathrm{H}-$ $\mathrm{AcOH}]^{+}, 269[\mathrm{M}+\mathrm{H}-2 \mathrm{xAcOH}]^{+}$. 
Reduction 9,10-Diacetyloxaspirol B Isomer $\mathbf{5 a - T o ~ a ~ s o l u t i o n ~ o f ~} \mathbf{5 a}(2.0 \mathrm{mg})$ in $\mathrm{MeOH}(0.3 \mathrm{~mL})$ and $\mathrm{CH}_{2} \mathrm{Cl}_{2}(0.2 \mathrm{~mL})$ at $0{ }^{\circ} \mathrm{C}$ was added $\mathrm{CeCl}_{3} \cdot 7 \mathrm{H}_{2} \mathrm{O}(10.0 \mathrm{mg})$, and the mixture was stirred at $0{ }^{\circ} \mathrm{C}$ for $5 \mathrm{~min}$. To this solution was added $\mathrm{NaBH}_{4}(0.5 \mathrm{mg})$. After disappearance of the starting material (TLC control), cold water $(5.0 \mathrm{~mL})$ was added to the reaction mixture, $\mathrm{MeOH}$ and $\mathrm{CH}_{2} \mathrm{Cl}_{2}$ were evaporated under reduced pressure, and products were extracted with EtOAc $(3 \times 5.0 \mathrm{~mL})$. The combined EtOAc extracts were washed with $\mathrm{H}_{2} \mathrm{O}$ and dried $\left(\mathrm{Na}_{2} \mathrm{SO}_{4}\right)$, and solvents were evaporated under reduced pressure; the resulting residue was purified by preparative TLC [silica gel, $\mathrm{CH}_{2} \mathrm{Cl}_{2}-\mathrm{MeOH}$ (99:2)] to give 9,10-diacetyldihydrooxaspirol B isomer $6 \mathbf{6}(1.6 \mathrm{mg}) ;{ }^{1} \mathrm{H}$ and ${ }^{13} \mathrm{C}$ NMR data, see Table S1.

4,9,10-Triacetyldihydrooxaspirol B Isomer 7a-To a solution of $\mathbf{6 a}(1.5 \mathrm{mg})$ in pyridine $(0.2 \mathrm{~mL})$ was added $\mathrm{Ac}_{2} \mathrm{O}(0.1 \mathrm{~mL})$, and the mixture was stirred at $25^{\circ} \mathrm{C}$. After 16 $\mathrm{h}$, the reaction mixture was evaporated under reduced pressure and residual pyridine was azeotrophed with EtOH to yield 7a (1.5 mg): colorless film; $[\alpha]_{\mathrm{D}}^{25}-187\left(c 1.4, \mathrm{CHCl}_{3}\right) ;{ }^{1} \mathrm{H}$ and ${ }^{13} \mathrm{C}$ NMR data, see Tables 2 and 3, respectively; APCI-MS (+) mode $\mathrm{m} / \mathrm{z} 373[\mathrm{M}+\mathrm{H}-$ $\mathrm{AcOH}]^{+}, 313[\mathrm{M}+\mathrm{H}-2 \mathrm{xAcOH}]^{+}, 253[\mathrm{M}+\mathrm{H}-3 \mathrm{xAcOH}]^{+}$.

Reduction 9,10-Diacetyloxaspirol B Isomer $\mathbf{5 b}$-To a solution of $\mathbf{5 b}(1.8 \mathrm{mg})$ in $\mathrm{MeOH}(0.3 \mathrm{~mL})$ and $\mathrm{CH}_{2} \mathrm{Cl}_{2}(0.2 \mathrm{~mL})$ at $0{ }^{\circ} \mathrm{C}$ was added $\mathrm{CeCl}_{3} .7 \mathrm{H}_{2} \mathrm{O}(10.0 \mathrm{mg})$, and the mixture was stirred at $0{ }^{\circ} \mathrm{C}$ for $5 \mathrm{~min}$. To this solution was added $\mathrm{NaBH}_{4}(0.5 \mathrm{mg})$. After disappearance of the starting material (TLC control), cold water $(5.0 \mathrm{~mL})$ was added to the reaction mixture, $\mathrm{MeOH}$ and $\mathrm{CH}_{2} \mathrm{Cl}_{2}$ were evaporated under reduced pressure, and the residue was extracted with EtOAc $(3 \times 5 \mathrm{~mL})$. The combined EtOAc extracts were washed with $\mathrm{H}_{2} \mathrm{O}$, dried $\left(\mathrm{Na}_{2} \mathrm{SO}_{4}\right)$, and evaporated under reduced pressure; the residue was purified by preparative TLC using [silica gel; $\mathrm{CH}_{2} \mathrm{Cl}_{2}-\mathrm{MeOH}$ (99:2)] to give 9,10-

diacetyldihydrooxaspirol B isomer $6 \mathbf{b}(1.5 \mathrm{mg}) ;{ }^{1} \mathrm{H}$ and ${ }^{13} \mathrm{C}$ NMR data, see Table S1.

4,9,10-Triacetyldihydrooxaspirol B Isomer (7b)-To a solution of $6 \mathbf{b}(1.2 \mathrm{mg})$ in pyridine $(0.2 \mathrm{~mL})$ was added $\mathrm{Ac}_{2} \mathrm{O}(0.1 \mathrm{~mL})$, and the mixture was stirred at $25^{\circ} \mathrm{C}$. After 16 $\mathrm{h}$ (TLC control), the reaction mixture was evaporated under reduced pressure and residual pyridine was azeotrophed with EtOH to yield 4,9,10-triacetyldihydrooxaspirol B isomer $\mathbf{7 b}$ (1.2 mg): colorless film; $[\alpha]_{\mathrm{D}}^{25}-197\left(\mathrm{c} 1.1, \mathrm{CHCl}_{3}\right) ;{ }^{1} \mathrm{H}$ and ${ }^{13} \mathrm{C}$ NMR data, see Tables 2 and 3 , respectively; APCI-MS (+) mode $m / z 373[\mathrm{M}+\mathrm{H}-\mathrm{AcOH}]^{+}, 313[\mathrm{M}+\mathrm{H}-2 \mathrm{xAcOH}]^{+}, 253$ $[\mathrm{M}+\mathrm{H}-3 \mathrm{xAcOH}]^{+}$.

Reduction Oxaspirol B (2)-To a stirred solution of 2 (10.0 mg) in $\mathrm{MeOH}(0.5 \mathrm{~mL})$ at $0{ }^{\circ} \mathrm{C}$ was added $\mathrm{CeCl}_{3} \cdot 7 \mathrm{H}_{2} \mathrm{O}(40.0 \mathrm{mg})$. After ca. $5 \mathrm{~min}$ at $0{ }^{\circ} \mathrm{C}, \mathrm{NaBH}_{4}(0.5 \mathrm{mg})$ was added and stirring continued at this tempearture. After disappearance of the starting material (TLC control), the reaction mixture was passed through a short column of silica gel and products were eluted with $\mathrm{CH}_{2} \mathrm{Cl}_{2}-\mathrm{MeOH}$ (98:2) to give an inseparable isomeric mixture of dihydrooxaspirols B 10a and 10b (8.7 mg).

Acetylation of Dihydrooxaspirol B Isomers (10a and 10b)-To a solution of 10a and $10 \mathbf{b}(3.1 \mathrm{mg})$ in pyridine $(0.2 \mathrm{~mL})$ was added $\mathrm{Ac}_{2} \mathrm{O}(0.3 \mathrm{~mL})$, and the mixture was stirred at $25^{\circ} \mathrm{C}$. After $16 \mathrm{~h}$ (TLC control), the reaction mixture solvents were evaporated 
under reduced pressure and residual pyridine was azeotrophed with EtOH to yield the crude product mixture which was separated by chiral HPLC [MeOH- $\mathrm{H}_{2} \mathrm{O}(72.5: 27.5), 0.8 \mathrm{~mL} /$ $\mathrm{min}$ ] to give 4,9,10-triacetyldihydrooxaspirol B isomers $\mathbf{1 a}\left(1.3 \mathrm{mg}, t_{\mathrm{R}}=24.2 \mathrm{~min}\right)$ and $\mathbf{7 b}$ $\left(1.4 \mathrm{mg}, t_{\mathrm{R}}=28.6 \mathrm{~min}\right)$, identical $\left({ }^{1} \mathrm{H}\right.$ and ${ }^{13} \mathrm{C}$ NMR and $\left.[a]_{\mathrm{D}}\right)$ with previously obtained samples.

Malachite Green Assay for p97 ATPase Activity-ATPase activity was evaluated using Malachite green as an indicator. The identical procedure was used for each protein. Assay buffer (50.0 mM HEPES pH 7.4, $\left.150.0 \mathrm{mM} \mathrm{KCl,} 10.0 \mathrm{mM} \mathrm{MgCl}_{2}, 2.0 \mathrm{mM} \mathrm{BME}\right)$ was prepared in $100.0 \mu \mathrm{L}$ reaction volume, and protein was added to $1.0 \mu \mathrm{M}$ followed by incubation at $37{ }^{\circ} \mathrm{C}$ for $10 \mathrm{~min}$; ATP hydrolysis was initiated by adding $2.0 \mathrm{mM}$ ATP to each microcentrifuge tube, followed by incubation at $37^{\circ} \mathrm{C}$. Aliquots $(20.0 \mu \mathrm{L})$ were taken at 2,4 , 6,8 , and $10 \mathrm{~min}$ and added immediately into $800.0 \mu \mathrm{L}$ of malachite green solution $(9.3 \mu \mathrm{M}$ malachite green, $53.0 \mathrm{mM}\left(\mathrm{NH}_{4}\right)_{2} \mathrm{MoO}_{4}, 1.0 \mathrm{M} \mathrm{HCl}, 10 \%$ Tween 20). After $1.0 \mathrm{~min}, 10.0$ $\mu \mathrm{L}$ of $34 \%$ sodium citrate was added and the $\mathrm{OD}_{660}$ was read on a Genesys $10 \mathrm{~S}$ Vis spectrophotometer (Thermo Scientific). For $\mathrm{IC}_{50}$ determination, 12-point dose response involving 2-fold serial dilutions (200.0, 100.0, 50.0, 25.0, 12.5, 6.25, 3.12, 1.56, 0.781, $0.391,0.195$, and $0 \mu \mathrm{M}$ ) was used.

Analysis of Covalent Reactivity of Oxaspirol B (2)_Aliquots of compound $\mathbf{2}$ in DMSO were added at $100.0 \mu \mathrm{M}$ final concentration to a $1.0 \mu \mathrm{M}$ solution of $\mathrm{p} 97$ in assay buffer (50.0 mM Tris, $150.0 \mathrm{mM} \mathrm{KCl,} 10.0 \mathrm{mM} \mathrm{MgCl}_{2}, 1.0 \mathrm{mM}$ DTT, pH 7.4) and incubated at $21^{\circ} \mathrm{C}$ for $6 \mathrm{~h}$. DMSO (1\%) was used as a vehicle control. The reaction was dialyzed into assay buffer for $2 \mathrm{~h}$ using Slide-A-Lyzer Dialysis Cassette (Thermo Scientific), and the buffer was exchanged for fresh buffer 3 times every $2 \mathrm{~h}$. The ATPase activity was then measured. To initiate the reaction, $2.0 \mathrm{mM}$ ATP was added. A $10.0 \mu \mathrm{L}$ aliquot was taken every $10 \mathrm{~min}$, up to $1 \mathrm{~h}$, and added to $800.0 \mu \mathrm{L}$ of malachite green solution. After 5 min, $100.0 \mu \mathrm{L}$ of $34 \%$ sodium citrate was added. $\mathrm{OD}_{660}$ values were collected on a Genesys 10S VIS spectrophotometer (Thermo Scientific), converted to $\mathrm{nM}$ inorganic phosphate using a standard curve, and plotted as a function of time using KaleidaGraph (Synergy Software).

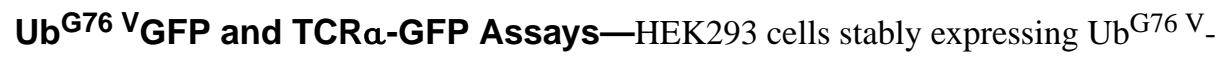
GFP or TCR $a$-GFP were kindly provided by Dr. Ron Kopito (Stanford University). For live cell imaging, HEK293 cells stably expressing $\mathrm{Ub}^{\mathrm{G} 76} \mathrm{~V}_{\text {GFP }}$ and TCR $\alpha$-GFP were seeded at $2 \times 10^{6}$ cells in phenol-red free Dulbecco's Modified Eagle Medium (DMEM) supplemented with $10 \%$ fetal bovine serum (FBS) on $35 \mathrm{~mm}$ glass-bottom dishes (Bio Express). After incubation at $37{ }^{\circ} \mathrm{C}$ under a $5 \% \mathrm{CO}_{2}$ atmosphere for $18 \mathrm{~h}$, each dish was treated with either $10.0,20.0$, or $50.0 \mu \mathrm{M}$ of $\mathbf{2}$ or $\mathbf{3}$ from DMSO stock solutions (0.1\% final DMSO concentration). DMSO $(0.1 \%)$ was used as a negative control. The cells were imaged in phenol-red free DMEM supplemented with 10\% FBS. Images were captured with an Observer Z1 microscope (Zeiss) by using the Slidebook 5.0 software (Intelligent Imaging Innovations). The fluorescence intensity was determined by flow cytometry on a FACScan flow cytometer (BD Biosciences) equipped with an air-cooled $15 \mathrm{~mW}$ argon ion laser tuned to $488 \mathrm{~nm}$. The emission fluorescence of GFP was detected and recorded through a 530/30 bandpass filter. List mode data files consisting of 10000 events gated on FSC (forward 
scatter) versus SSC (side scatter) were acquired and analyzed using CellQuest PROsoftware (BD Biosciences) at a rate of 200-400 events per second.

\section{Supplementary Material}

Refer to Web version on PubMed Central for supplementary material.

\section{ACKNOWLEDGMENTS}

Financial support for this work was provided by Grants R01 CA090265 funded by the National Cancer Institute, P41 GM094060 funded by National Institute of General Medical Sciences, R01 ES023758 funded by National Institute of Environmental Health Sciences, and DEB-0640996 funded by National Science Foundation. We also thank University of Arizona for start-up funds (E.C.) and CAPES, Brazil, for the graduate fellowship (V.M.C.).

\section{REFERENCES}

1. a Chapman E, Fry AN, Kang M. Mol. BioSyst. 2011; 7:700-710. [PubMed: 21152665] b Stolz A, Hilt W, Buchberger A, Wolf DH. Trends Biochem. Sci. 2011; 36:515-523. [PubMed: 21741246]

2. a Halawani D, Latterich M. Mol. Cell. 2006; 22:713-717. [PubMed: 16793541] b Meyer H, Bug M, Bremer S. Nat. Cell Biol. 2012; 14:117-123. [PubMed: 22298039]

3. Jentsch S, Rumpf S. Trends Biochem. Sci. 2007; 32:6-11. [PubMed: 17142044]

4. Rabinovich E, Kerem A, Fröhlich KU, Diamant N, Bar-Nun S. Mol. Cell. Biol. 2002; 22:626-634. [PubMed: 11756557]

5. Hoppe T, Matuschewski K, Rape M, Schlenker S, Ulrich HD, Jentsch S. Cell. 2000; 102:577-586. [PubMed: 11007476]

6. Latterich M, Fröhlich KU, Schekman R. Cell. 1995; 82:885-893. [PubMed: 7553849]

7. Pleasure IT, Black MM, Keen JH. Nature. 1993; 365:459-462. [PubMed: 8413590]

8. Chapman E, Maksim N, de la Cruz F, La Clair JJ. Molecules. 2015; 20:3027-3049. [PubMed: 25685910]

9. a Chou TF, Brown SJ, Minond D, Nordin BE, Li K, Jones AC, Chase P, Porubsky PR, Stoltz BM, Schoenen FJ, Patricelli MP, Hodder P, Rosen H, Deshaies RJ. Proc. Natl. Acad. Sci. U. S. A. 2011; 108:4834-4839. [PubMed: 21383145] b Chou TF, Li K, Frankowski KJ, Schoenen FJ, Deshaies RJ. ChemMedChem. 2013; 8:297-312. [PubMed: 23316025]

10. Santagata S, Xu Y, Wijeratne EMK, Kontnik R, Rooney C, Perley CC, Kwon H, Clardy J, Kesari S, Whitesell L, Lindquist S, Gunatilaka AA. L. ACS Chem. Biol. 2012; 7:340-349. [PubMed: 22050377]

11. Kang MJ, Wu T, Wijeratne EMK, Lau EC, Mason DJ, Mesa C, Tillotson J, Zhang DD, Gunatilaka AAL, La Clair JJ, Chapman E. ChemBioChem. 2014; 15:2125-2131. [PubMed: 25125376]

12. Lau EC, Mason DJ, Eichhorst N, Engelder P, Mesa C, Wijeratne EMK, Gunaherath GMKB, Gunatilaka AAL, La Clair JJ, Chapman E. Org. Biomol. Chem. 2015; 13:2255-2259. [PubMed: 25588099]

13. Johnson SM, Sharif O, Mak PA, Wang HT, Engels IH, Brinker A, Schultz PG, Horwich AL, Chapman E. Bioorg. Med. Chem. Lett. 2014; 24:786-789. [PubMed: 24418775]

14. Stack JH, Whitney M, Rodems SM, Pollok BA. Nat. Biotechnol. 2000; 18:1298-1302. [PubMed: 11101811]

15. Cross BC, McKibbin C, Callan AC, Roboti P, Piacenti M, Rabu C, Wilson CM, Whitehead R, Flitsch SL, Pool MR, High S, Swanton EJ. Cell Sci. 2009; 122:4393-4400.

16. Ayer WA, Cruz ER, Kawahara N, Muir DJ, Ptaszynska K. Rev. Latinoam. Quim. 1996; 24:183190.

17. Ayer WA, Kawahara N. Tetrahedron Lett. 1995; 36:7953-7956.

18. Sugijanto NE, Diesel A, Ebel R, Indrayanto G, Zaini NC. Nat. Prod. Commun. 2009; 4:14851488. [PubMed: 19967979]

19. Doi J, Hirota A, Nakagawa M, Sakai H, Isogai A. Agric. Biol. Chem. 1985; 49:2247-2248. 
20. a Isogai, A.; Nakagawa, S.; Hirota, A.; Doi, A.; Nakanishi, O. 1987. Japan Patent JP 62135469b Isogai, A.; Nakagawa, S.; Hirota, A.; Doi, A.; Nakanishi, O. 1987. Japan Patent JP 62164679

21. Ayer WA, Craw PA, Neary J. Can. J. Chem. 1992; 70:1338-1347.

22. Oh H, Swenson DC, Gloer JB, Shearer CA. J. Nat. Prod. 2003; 66:73-79. [PubMed: 12542349]

23. a Hashimoto M, Tsushima T, Murakami T, Nomiya M, Takada N, Tanaka K. Bioorg. Med. Chem. Lett. 2008; 18:4228-4231. [PubMed: 18541425] b Murakami T, Tsushima T, Takada N, Tanaka K, Nihei K, Miura T, Hashimoto M. Bioorg. Med. Chem. 2009; 17:492-495. [PubMed: 19109021]

24. Guo H, Sun B, Gao H, Niu S, Liu X, Yao X, Che Y. Eur. J. Org. Chem. 2009; 2009:5525-5530.

25. a Su BN, Park EJ, Mbwambo ZH, Santarsiero BD, Mesecar AD, Fong HH, Pezzuto JM, Kinghorn AD. J. Nat. Prod. 2002; 65:1278-1282. [PubMed: 12350147] b Seco JM, Quiñoá E, Riguera R. Chem. Rev. 2004; 104:17-117.

26. Kvasnica M, Sarek J, Vlk M, Budesinsky M, Stepanek O, Kubelka T, Plutnarova I. Tetrahedron: Asymmetry. 2011; 22:1011-1020.

27. Gersch M, Kreuzer J, Sieber SA. Nat. Prod. Rep. 2012; 29:659-682. [PubMed: 22504336]

28. Zheng L, Baumann U, Reymond JL. Nucleic Acids Res. 2004; 32:e115. [PubMed: 15304544]

29. Horwich AL, Fenton WA, Chapman E, Farr GW. Annu. Rev. Cell Dev. Biol. 2007; 23:115-145. [PubMed: 17489689]

30. Baker TA, Sauer RT. Biochim. Biophys. Acta, Mol. Cell Res. 2012; 1823:15-28.

31. Zhao C, Smith EC, Whiteheart SW. Biochim. Biophys. Acta, Mol. Cell Res. 2012; 1823:159-171.

32. Tao S, Tillotson J, Wijeratne EMK, Xu Y, Kang M, Wu T, Lau EC, Mesa C, Mason DJ, Brown RV, La Clair JJ, Gunatilaka AAL, Zhang DD, Chapman E. ACS Chem. Biol. 2015; 10:1916-1924. [PubMed: 26006219]

33. U'Ren JM, Lutzoni F, Miadlikowska J, Laetsch AD, Arnold AE. Am. J. Bot. 2012; 99:898-914. [PubMed: 22539507]

34. Ewing B, Green P. Genome Res. 1998; 8:186-194. [PubMed: 9521922]

35. Ewing B, Hillier L, Wendl MC, Green P. Genome Res. 1998; 8:175-185. [PubMed: 9521921]

36. Maddison, WP.; Maddison, DR. Mesquite. 2011. www.mesquiteproject.org

37. Liu KL, Porras-Alfaro A, Kuske CR, Eichorst SA, Xie G. Appl. Environ. Microbiol. 2012; 78:1523-1533. [PubMed: 22194300]

38. Altschul SF, Gish W, Miller W, Myers EW, Lipman DJ. J. Mol. Biol. 1990; 215:403-410. [PubMed: 2231712]

39. Maddison, DR.; Maddison, WP. MacClade, v. 4.08a. 2005. http://macclade.org

40. Del Olmo Ruiz, M. Ph.D. Dissertation. University of Arizona; Tucson, AZ: 2012. Diversity, distributions, and host affiliations of fungal endophytes associated with seedless vascular plants..

41. Zwickl, DJ. Ph.D. Dissertation. The University of Texas at Austin; Austin, TX: 2008. Genetic algorithm approaches for the phylogenetic analysis of large biological sequence datasets under the maximum likelihood criterion.; p. 1-114.

42. Posada D, Crandall KA. Bioinformatics. 1998; 14:817-818. [PubMed: 9918953]

43. Weber E. Nova Hedwigia. 2002; 74:159-185. 


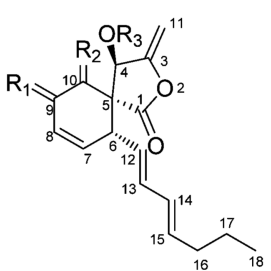

$\mathrm{R}_{1}$

Oxaspirol A (1) $\alpha-\mathrm{H}, \beta-\mathrm{OH} \quad \alpha-\mathrm{OH}, \beta-\mathrm{H} \quad \mathrm{H}$

Oxaspirol C (3) $\alpha-\mathrm{H}, \beta-\mathrm{OH} \quad \alpha-\mathrm{H}, \beta-\mathrm{OH} \quad \mathrm{H}$

(1a) $\alpha-\mathrm{H}, \beta-\mathrm{OAC} \alpha-\mathrm{OAc}, \beta-\mathrm{H}$ Ac

(3a) $\alpha-\mathrm{H}, \beta$-OAc $\alpha-\mathrm{H}, \beta-\mathrm{OAc}$ Ac

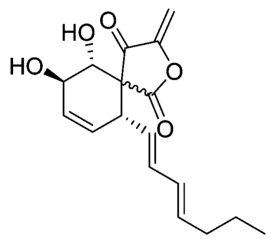

Oxaspirol B (2)

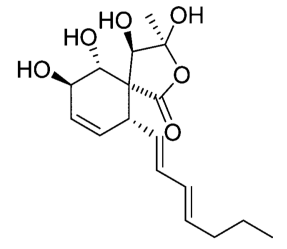

Oxaspirol D (4)

Figure 1.

Structures of oxaspirols A-D (1-4) and triacetates of oxaspirols A (1a) and C (3a). 
A

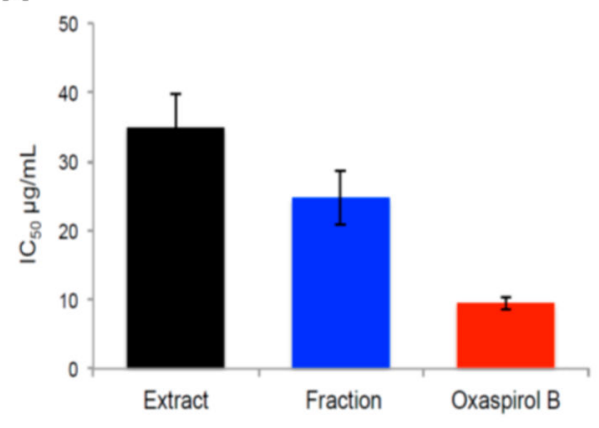

B

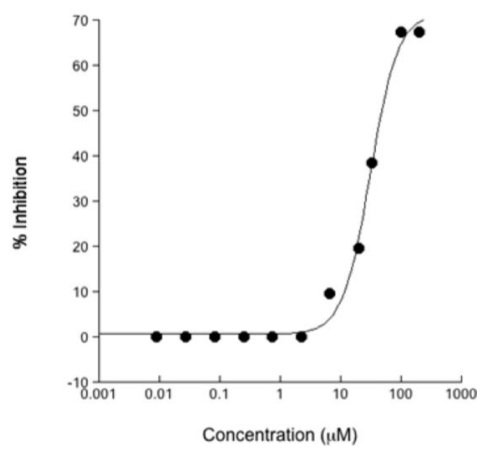

Figure 2.

p97 inhibitory activity data. (A) Bioactivity-guided fractionation of the bioactive extract of Lecythophora sp. FL1375 illustrating $\mathrm{IC}_{50}$ values of the extract $(34.9 \pm 4.7 \mu \mathrm{g} / \mathrm{mL})$, fraction $\mathrm{K}(24.7 \pm 4.0 \mu \mathrm{g} / \mathrm{mL})$, and oxaspirol B (2) $(9.5 \pm 0.9 \mu \mathrm{g} / \mathrm{mL})$. (B) Dose-response curve for p97 inhibitory activity of oxaspirol B $\left(\mathrm{IC}_{50}=31.2 \pm 3.0 \mu \mathrm{M}\right)$. 


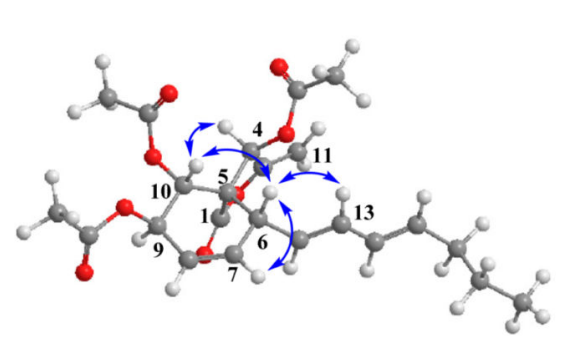

$1 \mathbf{a}$

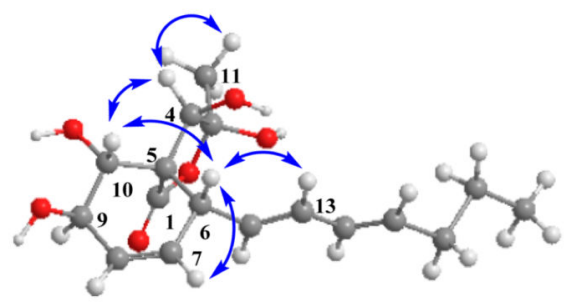

4

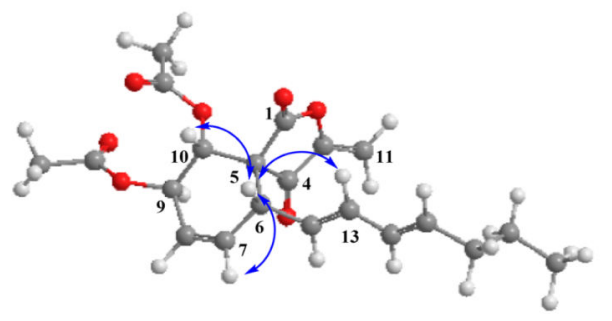

$\mathbf{5 b}$

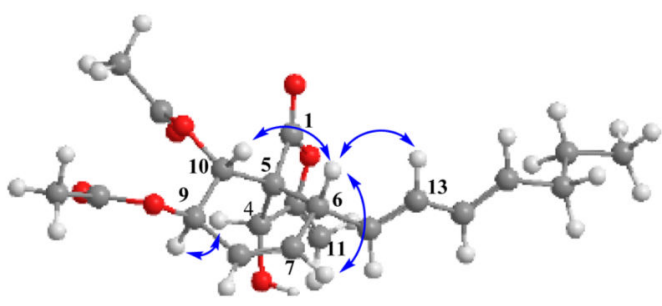

6b

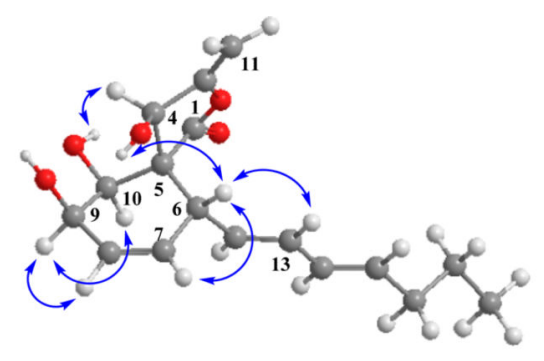

3

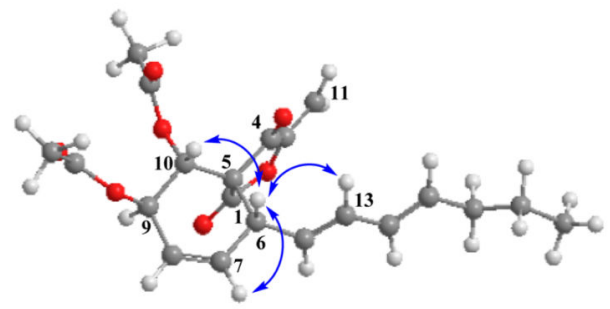

$5 \mathbf{a}$

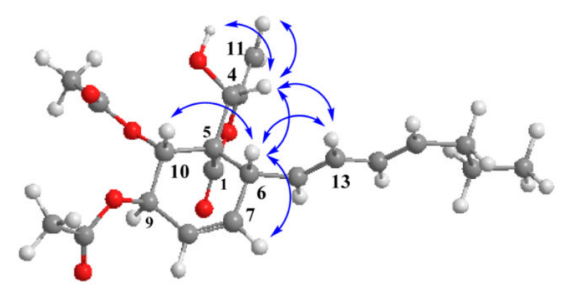

6a

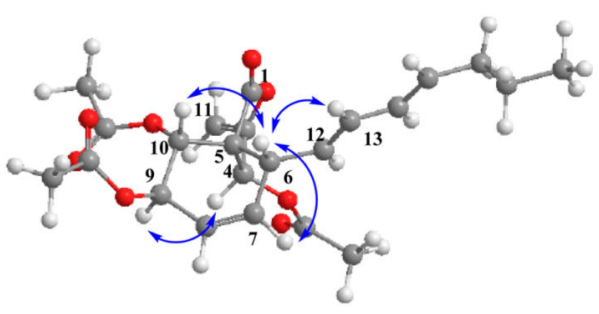

$7 \mathbf{b}$

\section{$\frown \mathrm{NOE}$}

Figure 3.

Key NOE correlations for 4,9,10-triacetyloxaspirol A (4,9,10-triacetyldihydrooxaspirol B isomer) (1a), oxaspirol C (3), oxaspirol D (4), 9,10-diacetyloxaspirol B isomers (5a and 5b), 9,10-diacetyldihydrooxaspirol B isomers (6a and $\mathbf{6 b}$ ), and 4,9,10-triacetyldihydrooxaspirol B isomer (7b). 


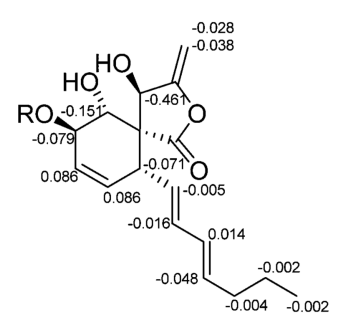

1b: $\mathrm{R}=(S)$-MTPA

1c: $\mathrm{R}=(R)$-MTPA

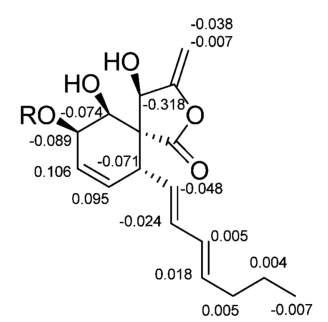

3a: $\mathrm{R}=(S)$-MTPA

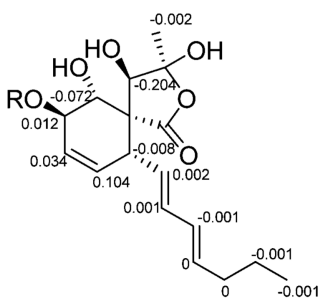

4a: $\mathrm{R}=(S)$-MTPA

4b: $\mathrm{R}=(R)$-MTPA

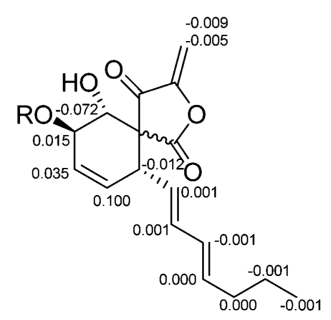

8a: $\mathrm{R}=(S)$-MTPA

8b: $\mathrm{R}=(R)$-MTPA

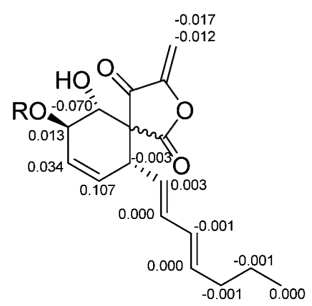

9a: $\mathrm{R}=(S)$-MTPA

9b: $\mathrm{R}=(R)-\mathrm{MTPA}$

Figure 4.

$\Delta \delta_{\mathrm{H}}$ values $\left[\Delta \delta\left(\right.\right.$ in ppm) $\left.=\delta_{\mathrm{S}}-\delta_{\mathrm{R}}\right]$ obtained for $(S)$ - and $(R)$-MTPA esters of oxaspirols A$\mathrm{D}(\mathbf{1}-\mathbf{4})$. 

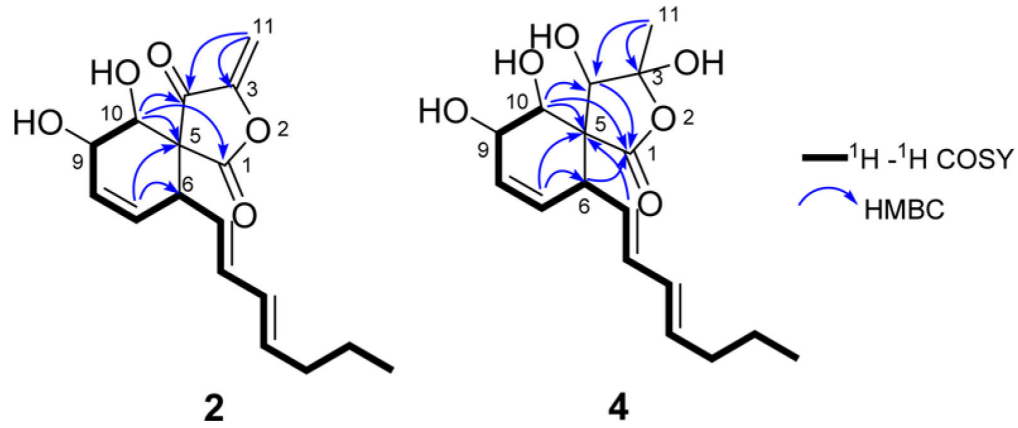

Figure 5.

Selected ${ }^{1} \mathrm{H}-{ }^{1} \mathrm{H}$ COSY and HMBC correlations for oxaspirols B (2) and D (4). 


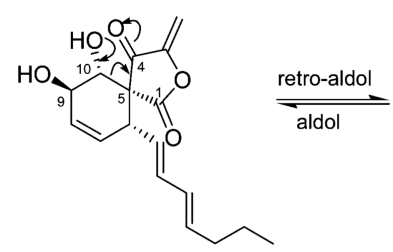

(2a)

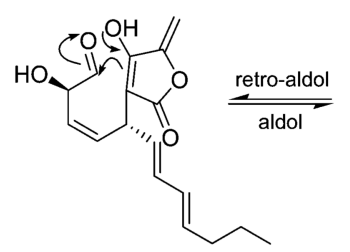

tro-aldo

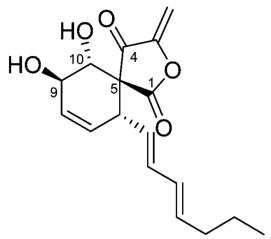

(2b)

Scheme 1.

Dynamic Equilibrium between Oxaspirol B (2) Isomers, $(5 R)$-Oxaspirol B (2a) and (5S)Oxaspirol B (2b), via retro-Aldol and Aldol Processes 


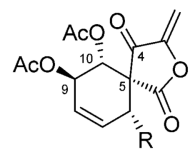

(5a)

$\downarrow$ (iii)

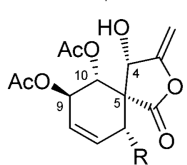

(6a)

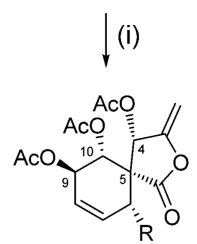

(7a)

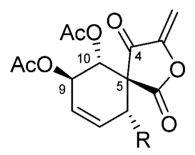

(5b)

$\downarrow$ (iii) (i), (ii)

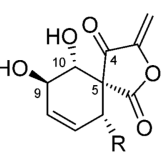

(2a)

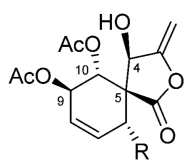

(6b)

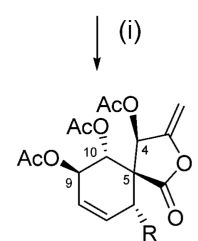

(7b)

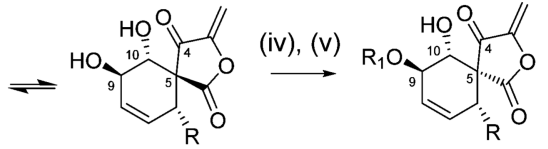

(2b)

(iii)

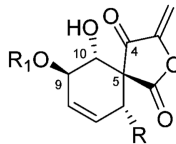

(9a) $\mathrm{R}_{1}=(S)-M T P A$

(9b) $\mathrm{R}_{1}=(R)-\mathrm{MTPA}$ (8b) $\mathrm{R}_{1}=(R)-\mathrm{MTPA}$
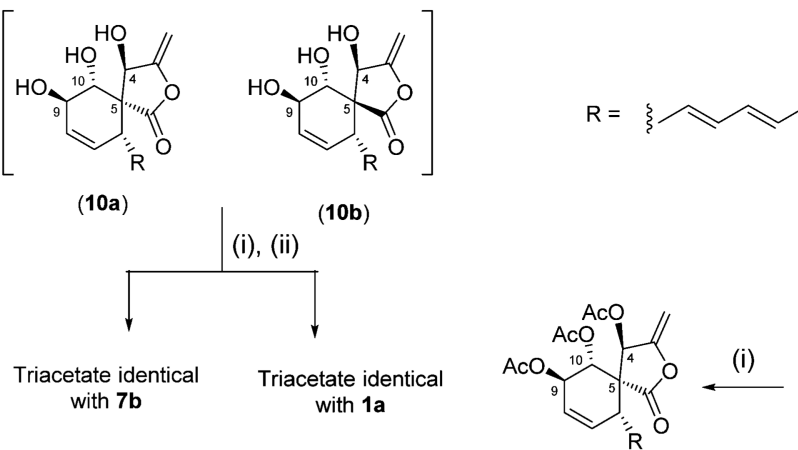

(1a)

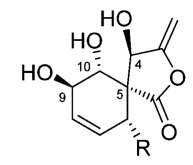

Oxaspirol A (1)

${ }^{a}$ Processes involved (i) acetylation $\left(\mathrm{Ac}_{2} \mathrm{O} /\right.$ pyridine); (ii) separation by chiral RP-HPLC; (iii) regiospecific reduction $\left(\mathrm{NaBH}_{4} / \mathrm{CeCl}_{3}\right)$; (iv) $\mathrm{Mosher}$ 's ester preparation $[(R)$ - or $(S)-\mathrm{MTPA}-\mathrm{Cl} /$ pyridine $]$; and $(\mathrm{v})$ separation by preparative TLC.

Scheme 2.

Derivatization of Oxaspirol B (2) and Separation of Derivatives of Its Isomers, $(5 R)$ -

Oxaspirol B (2a) and (5S)-Oxaspirol B (2b), and Acetylation of Oxaspirol A (1) ${ }^{a}$ 
(A)

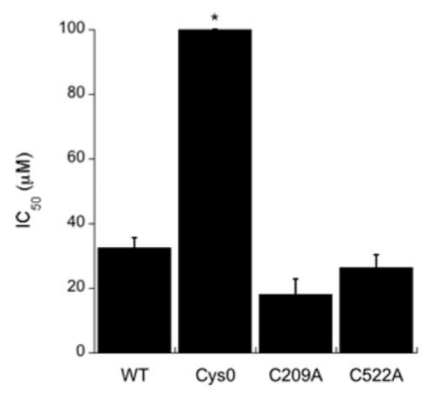

(B)

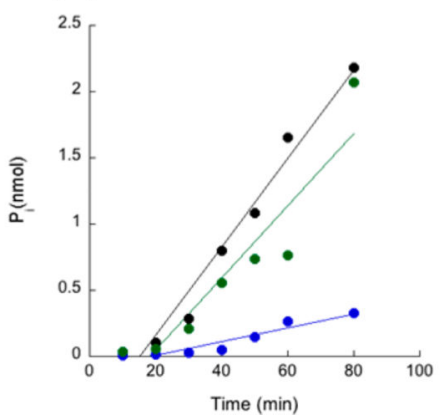

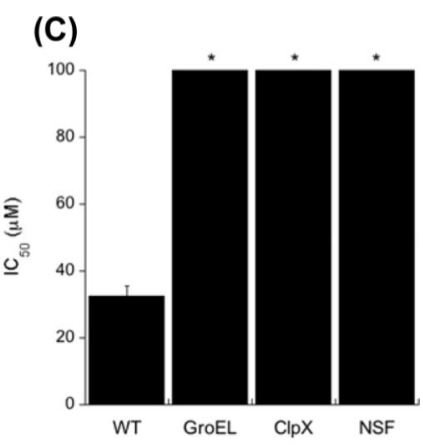

Figure 6.

Reversible inhibition of p97 by oxaspirol B (2). (A) 2 shows no activity against the cysteineless p97 variant, Cys0, but shows activity against the wild-type (WT) $\left(\mathrm{IC}_{50}=32.5 \pm 3.2 \mu \mathrm{M}\right)$ and the two ATPase pocket mutants $\mathrm{C} 209 \mathrm{a}\left(\mathrm{IC}_{50}=18.0 \pm 4.7 \mu \mathrm{M}\right)$ and $\mathrm{C} 522 \mathrm{~A}\left(\mathrm{IC}_{50}=26.3\right.$ $\pm 3.6 \mu \mathrm{M}$ ). (B) p97 ATPase activity is restored after prolonged incubation with 2 (green) followed by extensive dialysis relative to the vehicle control (black). In contrast, the covalent inhibitor dehydrocurvularin leads to continued inhibition even after extensive dialysis (blue) (unpublished data). (C) $\mathbf{2}$ is specific for p97 relative to other ATPases. Note: In both panels A and C, asterisks above bars indicate that concentrations used were greater than $200.0 \mu \mathrm{M}$. 
(A)

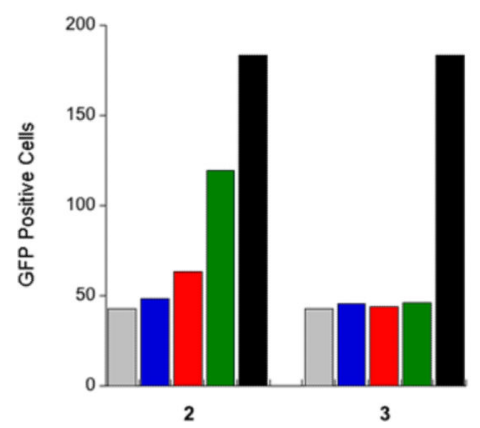

(B)

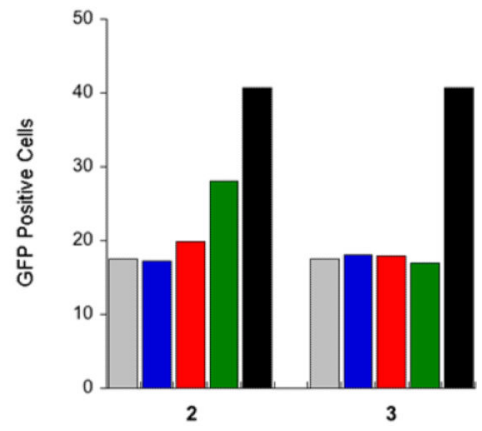

Figure 7.

Effects of oxaspirol B (2) and oxaspirol C (3) on p97-related cellular activities. (A) The p97dependent ubiquitin proteasome reporter, $\mathrm{Ub}^{\mathrm{G} 76} \mathrm{~V}_{\mathrm{GFP}}$, is rescued in the presence of 2 in a dose-dependent manner but not in the presence of 3. (B) The ERAD reporter, TCR $a$-GFP is rescued in the presence of $\mathbf{2}$ in a dose-dependent manner but not $\mathbf{3}$. Note: In both panels $\mathrm{A}$ and $\mathrm{B}$, the $y$-axis represents the number of GFP positive cells as determined by FACS. For each case, gray and black bars represent DMSO control and the positive control (MG132 at $10.0 \mu \mathrm{M})$, respectively, whereas blue, red, and green bars represent compounds $\mathbf{2}$ and $\mathbf{3}$ at concentrations of $10.0,20.0$, and $50.0 \mu \mathrm{M}$, respectively. 


\section{Table 1}

${ }^{1} \mathrm{H}$ NMR (400 MHz) and ${ }^{13} \mathrm{C}(100 \mathrm{MHz})$ NMR Spectroscopic Data for Oxaspirols A (1), C (3), and D (4) ${ }^{a}$

\begin{tabular}{|c|c|c|c|c|c|c|}
\hline \multirow[b]{2}{*}{ position } & \multicolumn{2}{|r|}{$\mathbf{1}^{b}$} & \multicolumn{2}{|r|}{$3^{c}$} & \multicolumn{2}{|r|}{$4^{b}$} \\
\hline & $\delta_{\mathrm{C}}($ type $)$ & $\delta_{\mathrm{H}}(J$ in $\mathbf{H z})$ & $\delta_{\mathrm{C}}($ type $)$ & $\delta_{\mathrm{H}}(J$ in $\mathbf{H z})$ & $\delta_{\mathrm{C}}($ type $)$ & $\delta_{\mathrm{H}}(J$ in $\mathbf{H z})$ \\
\hline 1 & $174.5(\mathrm{C})$ & & $171.4(\mathrm{C})$ & & $171.4(\mathrm{C})$ & \\
\hline 3 & $156.5(\mathrm{C})$ & & $155.5(\mathrm{C})$ & & $111.4(\mathrm{C})$ & \\
\hline 4 & $70.5(\mathrm{CH})$ & $5.13 \mathrm{br}$ & $68.9(\mathrm{CH})$ & $5.26, \mathrm{dd}(4.8,2.5)$ & $82.3(\mathrm{CH})$ & $4.24 \mathrm{~s}$ \\
\hline 5 & $56.6(\mathrm{C})$ & & $56.5(\mathrm{C})$ & & $59.1(\mathrm{C})$ & \\
\hline 6 & $39.3(\mathrm{CH})$ & $3.52 \mathrm{~m}$ & $40.6(\mathrm{CH})$ & $3.32, \mathrm{dd}(88,4.3)$ & $41.1(\mathrm{CH})$ & 3.26 brd (9.6) \\
\hline 7 & $130.4(\mathrm{CH})$ & $5.57 \mathrm{~m}$ & $133.1(\mathrm{CH})$ & $5.77, \mathrm{~m}$ & $131.0(\mathrm{CH})$ & $5.55 \mathrm{ddd}(10.4,1.8,1.6)$ \\
\hline 8 & $126.8(\mathrm{CH})$ & $5.74 \mathrm{dt}(10.4,2.4)$ & $123.9(\mathrm{CH})$ & $5.81, \mathrm{~m}$ & $127.9(\mathrm{CH})$ & $5.60 \mathrm{dd}(10.4,1.6)$ \\
\hline 9 & $69.0(\mathrm{CH})$ & $4.70 \mathrm{br}$ & $65.9(\mathrm{CH})$ & $4.39, \mathrm{~m}$ & $70.5(\mathrm{CH})$ & $4.23 \mathrm{~m}$ \\
\hline 10 & $72.9(\mathrm{CH})$ & $3.81 \mathrm{~d}(6.4)$ & $65.8(\mathrm{CH})$ & $4.38, \mathrm{~m}$ & $79.8(\mathrm{CH})$ & $4.07 \mathrm{~d}(8.4)$ \\
\hline \multirow[t]{2}{*}{11} & $89.6\left(\mathrm{CH}_{2}\right)$ & $4.79 \mathrm{t}(2.4)$ & $90.5\left(\mathrm{CH}_{2}\right)$ & $4.92, \mathrm{t}(2.5)$ & $15.5\left(\mathrm{CH}_{3}\right)$ & $1.64 \mathrm{~s}$ \\
\hline & & $4.66 \mathrm{t}(2.4)$ & & $4.75, \mathrm{t}(2.5)$ & & \\
\hline 12 & $127.3(\mathrm{CH})$ & $5.38 \mathrm{dd}(15.2,8.8)$ & $126.7(\mathrm{CH})$ & $5.32, \mathrm{dd}(14.3,8.9)$ & $127.1(\mathrm{CH})$ & $5.98 \mathrm{dd}(15.2,9.6)$ \\
\hline 13 & $135.0(\mathrm{CH})$ & $6.07 \mathrm{dd}(14.8,10.0)$ & $134.1(\mathrm{CH})$ & $5.98, \mathrm{~m}$ & $134.6(\mathrm{CH})$ & $6.21 \mathrm{dd}(15.2,10.4)$ \\
\hline 14 & $129.6(\mathrm{CH})$ & $5.90 \mathrm{dd}(15.2,10.8)$ & $129.4(\mathrm{CH})$ & $5.95, \mathrm{~m}$ & $129.1(\mathrm{CH})$ & $6.03 \mathrm{ddt}(15.2,10.4,1.6)$ \\
\hline 15 & $136.0(\mathrm{CH})$ & $5.64 \mathrm{~m}$ & $136.1(\mathrm{CH})$ & $5.67 \mathrm{dt}(13.9,7.3)$ & $136.2(\mathrm{CH})$ & $5.67 \mathrm{dt}(15.2,7.2)$ \\
\hline 16 & $34.9\left(\mathrm{CH}_{2}\right)$ & $2.00 \mathrm{q}(7.2)$ & $35.0\left(\mathrm{CH}_{2}\right)$ & $2.00 \mathrm{q}(7.3)$ & $34.6\left(\mathrm{CH}_{2}\right)$ & $2.02 \mathrm{~m}$ \\
\hline 17 & $22.5\left(\mathrm{CH}_{2}\right)$ & 1.36 sextet $(7.2)$ & $22.5\left(\mathrm{CH}_{2}\right)$ & 1.37 sextet $(7.3)$ & $22.3\left(\mathrm{CH}_{2}\right)$ & 1.38 sextet $(7.2)$ \\
\hline 18 & $13.9\left(\mathrm{CH}_{3}\right)$ & $0.87 \mathrm{t}(7.2)$ & $14.0\left(\mathrm{CH}_{3}\right)$ & $0.87 \mathrm{t}(7.3)$ & $14.6\left(\mathrm{CH}_{3}\right)$ & $0.88 \mathrm{t}(7.2)$ \\
\hline $4-\mathrm{OH}$ & & & & $3.75, \mathrm{~d}(4.8)$ & & \\
\hline 9-OH & & & & $2.47, \mathrm{brs}$ & & \\
\hline $10-\mathrm{OH}$ & & & & 2.86, brs & & \\
\hline
\end{tabular}


Table 2

${ }^{1} \mathrm{H}$ NMR $\left(\mathrm{CDCl}_{3}, 400 \mathrm{MHz}\right)$ Data for the Acetates Derived from Oxaspirols A and B ${ }^{a}$

\begin{tabular}{llllll}
\hline & $\mathbf{1 a}$ & $\mathbf{5 a}$ & $\mathbf{5 b}$ & $\mathbf{7 a}$ & $\mathbf{7 b}$ \\
position & $\boldsymbol{\delta}_{\mathbf{H}}(\boldsymbol{J}$ in $\mathbf{H z})$ & $\boldsymbol{\delta}_{\mathbf{H}}(\boldsymbol{J}$ in Hz) & $\boldsymbol{\delta}_{\mathbf{H}}(\boldsymbol{J}$ in Hz) & $\boldsymbol{\delta}_{\mathbf{H}}(\boldsymbol{J}$ in $\mathbf{H z})$ & $\boldsymbol{\delta}_{\mathbf{H}}(\boldsymbol{J}$ in $\mathbf{H z})$ \\
\hline 4 & $5.89, \mathrm{dd}(2.5,2.0)$ & & & $5.99, \mathrm{dd}(3.1,2.3)$ & $6.44, \mathrm{t}(2.3)$ \\
6 & $3.40, \mathrm{~m}$ & $3.51, \mathrm{~m}$ & $3.62, \mathrm{~m}$ & $3.44, \mathrm{~m}$ & $3.49, \mathrm{~m}$ \\
7 & $5.67, \mathrm{~m}$ & $5.70, \mathrm{~m}$ & $5.74-5.66, \mathrm{~m}$ & $5.61, \mathrm{dd}(10.0,1.8)$ & $5.68, \mathrm{~m}$ \\
8 & $5.55, \mathrm{dt}(10.3,2.1)$ & $5.58, \mathrm{dd}(10.0,2.1)$ & $5.59, \mathrm{dt}(10.0,2.1)$ & $5.57, \mathrm{dd}(10.0,1.4)$ & $5.51-5.46, \mathrm{~m}$ \\
9 & $6.03, \mathrm{dq}(8.0,2.2)$ & $5.91, \mathrm{~m}$ & $5.91, \mathrm{~m}$ & $5.72, \mathrm{~m}$ & $5.51-5.46, \mathrm{~m}$ \\
10 & $5.38, \mathrm{~d}(8.0)$ & $5.60, \mathrm{~d}(8.5)$ & $5.62, \mathrm{~d}(8.5)$ & $5.24, \mathrm{~d}(7.9)$ & $5.67, \mathrm{~d}(7.9)$ \\
11 & $4.77, \mathrm{dd}(3.2,2.5)$ & $5.39, \mathrm{~d}(3.1)$ & $5.43, \mathrm{~d}(3.1)$ & $4.82, \mathrm{t}(3.1)$ & $4.83, \mathrm{t}(2.7)$ \\
& $4.40, \mathrm{dd}(3.2,2.0)$ & $5.07, \mathrm{~d}(3.1)$ & $5.08, \mathrm{~d}(3.1)$ & $4.37, \mathrm{dd}(3.1,2.3)$ & $4.41, \mathrm{dd}(3.2,1.9)$ \\
12 & $5.41, \mathrm{dd}(15.3,8.3)$ & $5.21, \mathrm{dd}(15.1,9.2)$ & $5.11, \mathrm{dd}(15.1,9.2)$ & $5.32, \mathrm{dd}(15.0,10.0)$ & $5.58, \mathrm{dd}(15.3,9.6)$ \\
13 & $6.11, \mathrm{dd}(15.2,10.4)$ & $6.05, \mathrm{dd}(15.1,10.2)$ & $6.14, \mathrm{dd}(15.3,10.2)$ & $6.35, \mathrm{dd}(15.0,10.2)$ & $6.11, \mathrm{dd}(15.3,10.4)$ \\
14 & $5.91, \mathrm{dd}(15.1,10.4)$ & $5.87, \mathrm{dd}(14.6,10.7)$ & $5.84, \mathrm{dd}(15.3,10.7)$ & $5.99, \mathrm{dd}(15.0,10.2)$ & $5.92, \mathrm{dd}(15.3,10.2)$ \\
15 & $5.64, \mathrm{dd}(15.1,7.3)$ & $5.66, \mathrm{dd}(14.6,7.2)$ & $5.74-5.66, \mathrm{~m}$ & $5.75, \mathrm{dd}(15.0,7.3)$ & $5.69, \mathrm{dd}(15.3,7.2)$ \\
16 & $2.02, \mathrm{q}(7.3)$ & $2.00, \mathrm{q}(7.2)$ & $2.00, \mathrm{q}(7.2)$ & $2.03, \mathrm{q}(7.3)$ & $2.00, \mathrm{q}(7.2)$ \\
17 & $1.37, \mathrm{sextet}(7.3)$ & $1.35, \mathrm{sextet}(7.3)$ & $1.36, \mathrm{sextet}(7.3)$ & $1.39, \mathrm{sextet}(7.3)$ & $1.38, \mathrm{sextet}(7.2)$ \\
18 & $0.86, \mathrm{t}(7.3)$ & $0.85, \mathrm{t}(7.3)$ & $0.85, \mathrm{t}(7.3)$ & $0.88, \mathrm{t}(7.3)$ & $0.87, \mathrm{t}(7.2)$ \\
OAc & $2.19, \mathrm{~s}$ & $2.01, \mathrm{~s}$ & $2.02, \mathrm{~s}$ & $2.16, \mathrm{~s}$ & $2.13, \mathrm{~s}$ \\
OAc & $2.06, \mathrm{~s}$ & $1.91, \mathrm{~s}$ & $1.94, \mathrm{~s}$ & $2.00, \mathrm{~s}$ & $2.02, \mathrm{~s}$ \\
OAc & $2.00, \mathrm{~s}$ & & & $1.95, \mathrm{~s}$ & $2.01, \mathrm{~s}$
\end{tabular}

${ }^{a}$ Signals were assigned on the basis of ${ }^{1} \mathrm{H}_{-}{ }^{1} \mathrm{H}$ COSY, HSQC, and HMBC data. 
Table 3

${ }^{13} \mathrm{C}$ NMR $\left(\mathrm{CDCl}_{3}, 100 \mathrm{MHz}\right)$ Data for the Acetates Derived from Oxaspirols A and B ${ }^{a}$

\begin{tabular}{|c|c|c|c|c|c|}
\hline position & $\begin{array}{c}1 \mathrm{a} \\
\delta_{\mathrm{C}}, \text { type }\end{array}$ & $\begin{array}{c}5 \mathbf{a} \\
\delta_{\mathrm{C}}, \text { type }\end{array}$ & $\begin{array}{c}5 \mathbf{b} \\
\delta_{\mathrm{C}}, \text { type }\end{array}$ & $\begin{array}{c}7 \mathbf{a} \\
\delta_{\mathrm{C}}, \text { type }\end{array}$ & $\begin{array}{c}7 \mathbf{b} \\
\delta_{\mathrm{C}}, \text { type }\end{array}$ \\
\hline 1 & $169.5(\mathrm{C})$ & $167.9(\mathrm{CH})$ & $168.8(\mathrm{C})$ & $169.8(\mathrm{C})$ & $168.9(\mathrm{C})$ \\
\hline 3 & $152.7(\mathrm{C})$ & $150.4(\mathrm{C})$ & $150.3(\mathrm{C})$ & $153.3(\mathrm{C})$ & $152.8(\mathrm{C})$ \\
\hline 4 & $69.5(\mathrm{CH})$ & $194.2(\mathrm{C})$ & $192.6(\mathrm{C})$ & $70.8(\mathrm{CH})$ & $67.7(\mathrm{CH})$ \\
\hline 5 & $55.8(\mathrm{C})$ & $57.5(\mathrm{C})$ & 57.4 (C) & $54.8(\mathrm{C})$ & 57.7 (C) \\
\hline 6 & $41.1(\mathrm{CH})$ & $45.7(\mathrm{CH})$ & $46.0(\mathrm{CH})$ & $45.0(\mathrm{CH})$ & $46.6(\mathrm{CH})$ \\
\hline 7 & $129.2(\mathrm{CH})$ & $126.1(\mathrm{CH})$ & $126.2(\mathrm{CH})$ & $129.9(\mathrm{CH})$ & $131.9(\mathrm{CH})$ \\
\hline 8 & $125.0(\mathrm{CH})$ & $128.7(\mathrm{CH})$ & $128.4(\mathrm{CH})$ & $124.7(\mathrm{CH})$ & $124.1(\mathrm{CH})$ \\
\hline 9 & $71.1(\mathrm{CH})$ & $70.9(\mathrm{CH})$ & $69.9(\mathrm{CH})$ & $71.4(\mathrm{CH})$ & $71.0(\mathrm{CH})$ \\
\hline 10 & $71.3(\mathrm{CH})$ & $71.3(\mathrm{CH})$ & $71.9(\mathrm{CH})$ & $69.8(\mathrm{CH})$ & $71.4(\mathrm{CH})$ \\
\hline 11 & $90.1\left(\mathrm{CH}_{2}\right)$ & $96.1\left(\mathrm{CH}_{2}\right)$ & $96.0\left(\mathrm{CH}_{2}\right)$ & $88.5\left(\mathrm{CH}_{2}\right)$ & $90.3\left(\mathrm{CH}_{2}\right)$ \\
\hline 12 & $122.8(\mathrm{CH})$ & $122.8(\mathrm{CH})$ & $122.6(\mathrm{CH})$ & $124.9(\mathrm{CH})$ & $125.2(\mathrm{CH})$ \\
\hline 13 & $135.9(\mathrm{CH})$ & $136.0(\mathrm{CH})$ & $136.9(\mathrm{CH})$ & $137.6(\mathrm{CH})$ & $136.2(\mathrm{CH})$ \\
\hline 14 & $128.9(\mathrm{CH})$ & $128.5(\mathrm{CH})$ & $128.1(\mathrm{CH})$ & $129.0(\mathrm{CH})$ & $128.9(\mathrm{CH})$ \\
\hline 15 & $136.5(\mathrm{CH})$ & $137.3(\mathrm{CH})$ & $138.0(\mathrm{CH})$ & $137.2(\mathrm{CH})$ & $136.9(\mathrm{CH})$ \\
\hline 16 & $34.7\left(\mathrm{CH}_{2}\right)$ & $34.7\left(\mathrm{CH}_{2}\right)$ & $34.7\left(\mathrm{CH}_{2}\right)$ & $34.7\left(\mathrm{CH}_{2}\right)$ & $34.7\left(\mathrm{CH}_{2}\right)$ \\
\hline 17 & $22.3\left(\mathrm{CH}_{2}\right)$ & $22.1\left(\mathrm{CH}_{2}\right)$ & $22.1\left(\mathrm{CH}_{2}\right)$ & $22.2\left(\mathrm{CH}_{2}\right)$ & $22.2\left(\mathrm{CH}_{2}\right)$ \\
\hline 18 & $13.7\left(\mathrm{CH}_{3}\right)$ & $13.6\left(\mathrm{CH}_{3}\right)$ & $13.6\left(\mathrm{CH}_{3}\right)$ & $13.7\left(\mathrm{CH}_{3}\right)$ & $13.7\left(\mathrm{CH}_{3}\right)$ \\
\hline OAc & $170.4(\mathrm{C}) ; 21.0\left(\mathrm{CH}_{3}\right)$ & $170.5(\mathrm{C}) ; 21.0\left(\mathrm{CH}_{3}\right)$ & $170.5(\mathrm{C}) ; 21.0\left(\mathrm{CH}_{3}\right)$ & $170.4(\mathrm{C}) ; 21.0\left(\mathrm{CH}_{3}\right)$ & $171.4(\mathrm{C}) ; 21.0\left(\mathrm{CH}_{3}\right)$ \\
\hline $\mathrm{OAc}$ & $169.8(\mathrm{C}) ; 20.7\left(\mathrm{CH}_{3}\right)$ & $168.9(\mathrm{C}) ; 20.4\left(\mathrm{CH}_{3}\right)$ & $170.1(\mathrm{C}) ; 20.4\left(\mathrm{CH}_{3}\right)$ & $170.3(\mathrm{C}) ; 20.8\left(\mathrm{CH}_{3}\right)$ & $170.5(\mathrm{C}) ; 20.4\left(\mathrm{CH}_{3}\right)$ \\
\hline OAc & $169.5(\mathrm{C}) ; 20.6\left(\mathrm{CH}_{3}\right)$ & & & $169.4(\mathrm{C}) ; 20.5\left(\mathrm{CH}_{3}\right)$ & $169.0(\mathrm{C}) ; 20.6\left(\mathrm{CH}_{3}\right)$ \\
\hline
\end{tabular}

${ }^{a}$ Signals were assigned on the basis of HSQC data. 